\title{
The Economic Effects of the 2018 U.S. Trade Policy: A State-Level Analysis
}

\author{
Ana Maria Santacreu and Makenzie Peake
}

\begin{abstract}
We evaluate, empirically, the effect of changes in trade policy during the 2018-19 trade war on U.S. economic activity. We begin by documenting that sectors and states across the United States are heterogeneous in their exposure to international trade. To do that, we construct a measure of exposure that combines the share of a sector's gross output that is accounted for by trade with the pattern of comparative advantage of each state in that sector. We then exploit cross-state heterogeneity in exposure to international trade and correlate it with measures of economic activity across U.S. states. Our findings suggest that states that were very exposed to trade at the onset of the trade war experienced worse outcomes in terms of employment and output growth. Our analysis is not aimed at concluding any causality effects, but instead focuses on correlations. (JEL F10, F13, F14)
\end{abstract}

Federal Reserve Bank of St. Louis Review, Fourth Quarter 2020, 102(4), pp. 385-412. https://doi.org/10.20955/r.102.385-412

\section{INTRODUCTION}

The U.S. trade policy that started in 2017 has spiraled into a return to protectionism. The trade war began with recommendations from the U.S. administration to implement tariffs on specific goods (e.g., solar panels, washing machines, and steel and aluminum) in an attempt to protect national security and mitigate negative impacts faced by domestic producers of such products. 1 Tariffs on these goods were enacted in 2018 and were followed by retaliatory tariffs from China, along with retaliatory tariffs from the European Union (EU) and Canada on steel, aluminum, and agricultural products. The United States has continued to levy tariffs onto major trading partners such as Canada, Mexico, the EU, and China. ${ }^{2}$ Perhaps the most noteworthy battle in the tariff front exists between the United States and China, given the growing tension between the two countries as the trade war progresses.

In this article, we exploit variation in sector-state exposure to international trade and evaluate, empirically, the effect of trade policy on U.S. output growth and employment. Recent papers have explored the effect of the trade war on the United States through the lens of a

Ana Maria Santacreu is a senior economist and Makenzie Peake was a research associate at the Federal Reserve Bank of St. Louis.

(c) 2020, Federal Reserve Bank of St. Louis. The views expressed in this article are those of the author(s) and do not necessarily reflect the views of the Federal Reserve System, the Board of Governors, or the regional Federal Reserve Banks. Articles may be reprinted, reproduced, published, distributed, displayed, and transmitted in their entirety if copyright notice, author name(s), and full citation are included. Abstracts, synopses, and other derivative works may be made only with prior written permission of the Federal Reserve Bank of St. Louis. 


\section{Santacreu and Peake}

quantitative model (see Caldara et al., 2019; Fajgelbaum et al., 2019; and Santacreu, Sposi, and Zhang, 2019). However, empirical studies have been rather limited. We try to fill that gap by providing an empirical analysis of the effects of a trade war on the United States.

We start by constructing a measure of initial sectoral exposure to international trade, from the perspective of both imports and exports. We focus on trade in intermediate goods and abstract from final goods, as tariff announcements have fallen mainly onto intermediate goods. We use data for 19 sectors from the World Input-Output Database (WIOD) 2016 Release for 2014-the latest year available in the WIOD, prior to the trade war. We then compute, for each sector, a measure of trade exposure as the ratio of U.S. total trade of intermediate products with the world to U.S. gross output in that sector. To the extent that U.S. states specialize in the production of different sectors, exposure to trade policy will likely be heterogeneous across states. $\underline{3}$ To capture this idea, we combine our measure of sectoral trade exposure with the production composition of each U.S. state — calculated as the share of value added of each sector in that state-and compute a measure of trade exposure at the state level. It is important to note that this measure of trade exposure does not rely on actual tariff data. We interpret it as a sector's overall trade exposure that depends only on data of traded intermediate goods by sector, regardless of actual trade policy.

We find that the sectors most exposed to imports-those that rely more heavily on imported intermediate products-are Coke and petroleum and Motor vehicles and trailers. Mining and quarrying and Forestry, fishing, and logging are the sectors least exposed. With respect to exports, the sectors most exposed-those that export more intermediate goods to the world-are Other transport equipment and Computer, electronic, and optical, and the sectors least exposed are Mining and quarrying and Other non-metallic mineral products. Louisiana and Michigan are very exposed to imports from the world. Louisiana specializes in Coke and petroleum, and Michigan specializes in Motor vehicles and trailers. Alaska and North Dakota are the states least exposed to imports, as they both specialize in Mining and quarrying. In the case of exports, Washington and California are very exposed, whereas Alaska and Wyoming are among the states least exposed.

We then follow an approach similar to Mian and Sufi (2009) to exploit the observed crossstate heterogeneity in exposure to international trade and correlate it with measures of economic activity across U.S. states. We focus on quarterly growth rates of employment and output between 2018:Q1 and 2019:Q1. We find the following: (i) There is a negative and significant correlation between the initial exposure to trade and economic activity; (ii) the negative correlation is stronger with employment growth than it is with output growth; and (iii) the negative correlation is stronger with import exposure than it is with export exposure. That is, those states more exposed to trade experienced lower increases or even decreases in output growth and employment growth between 2018 and 2019. These findings reflect that firms operating in states very exposed to trade adjusted their employment and production decisions after announcements of tariff increases. The adjustments were stronger in terms of employment than in terms of output, and they were stronger in states very exposed to U.S. tariffs than in states very exposed to retaliatory tariffs. Obviously, there are economic forces other than trade exposure that could be driving heterogeneous adjustments in employment and production 
across U.S. states. Our analysis is not aimed at concluding any causality effects. However, the strong negative correlation found in the data suggests that initial trade exposure could have played a role in those adjustments.

Finally, we analyze the effect of the 2018-19 U.S.-China trade war on U.S. economic activity. We construct exposure measures that use actual U.S. tariffs imposed on China and subsequent retaliatory Chinese tariffs. The measure of import exposure exploits the input-output structure of the economy, as it captures that those sectors that depend more on imports from sectors with larger increases of U.S. tariffs are more exposed to imports from China. These are Motor vehicles and trailers and Machinery and equipment, n.e.c. In the case of export exposure, sectors that the United States exports most or that are subject to higher retaliatory Chinese tariffs will be more exposed to trade with China. These are Other transport equipment and Agriculture. Heterogeneity in sector exposure translates into heterogeneity in state exposure, as states specialize in the production of different sectors. Michigan is very exposed to imports from China, whereas Washington is very exposed to exports. As before, we find a negative correlation-albeit a weaker one than in the case of exposure to the world-between our measures of trade exposure to China and both output growth and employment growth. In contrast to our previous results, the negative correlation is stronger with output growth than it is with employment growth, and it is stronger in the case of retaliatory tariffs.

Our results suggest that cross-state heterogeneity in trade exposure correlates negatively with U.S. economic activity. Although we cannot claim any causality effects, these findings are an indication that the trade war initiated by the United States may have had a stronger impact on U.S. employment and production than what is found through the lenses of standard models of trade. Accounting for this heterogeneity is thus key in capturing the negative impacts.

Our article is related to a very recent strand of literature on the effects of trade policy on the United States. Actual tariff increases, followed by the threat of future raises, have increased uncertainty in the tradable sector. According to several studies, higher uncertainty has already had a negative impact on the United States in terms of investment and production (see Caldara et al., 2019; Handley and Limão, 2015 and 2017; and Bloom, Bond, and Van Reenen, 2007).

Recent studies using quantitative models of trade have found small aggregate effects of tariffs on the U.S. economy. These studies, however, do not take into account the effect of uncertainty and focus their analysis on actual tariff increases. Despite small aggregate effects, these models find highly heterogeneous effects of tariffs across both sectors and states (see Fajgelbaum et al., 2019; Amiti, Redding, and Weinstein, 2019; Auer, Bonadio, and Levchenko, 2018; and Santacreu, Sposi, and Zhang, 2019), which could potentially have heterogeneous effects on economic activity across U.S. states. Our article differs from those studies in that we explore empirically - rather than through the lens of a quantitative model — whether heterogeneous exposure to trade had an impact on economic outcomes.

\section{HETEROGENEOUS IMPACT OF TRADE POLICY ACROSS U.S. STATES}

In this section, we evaluate the effect of changes in trade policy on economic activity across U.S. states. We start by computing a measure of initial sectoral exposure to international 


\section{Santacreu and Peake}

trade with the world. We then combine that measure with the production structure of each state across different sectors to obtain a measure of state trade exposure. Finally, we use an approach akin to Mian and Sufi (2009) and exploit cross-state variation in initial trade exposure to evaluate the impact of trade policy on state employment and output growth.

\subsection{Sectoral Trade Exposure}

Our first observation is that sectors in the United States are exposed to international trade differently. Using data for 2014 from the WIOD, 2016 Release, we compute a measure of initial trade exposure at the sector level. The idea is to calculate a measure of trade exposure prior to the announcement or the actual change in tariffs, as trade flows may change when tariffs are either announced or actually implemented. By looking at initial trade flows, our exposure measure is not affected by these changes.

Specifically, we compute sector $j$ 's exposure to trade between the United States and the world, with $E_{\mathrm{US}, \mathrm{W}}^{j}$ as the ratio of total imports or exports of intermediates goods in a sector to U.S. gross output in that sector. ${ }^{4}$ That is,

$$
E_{\mathrm{US}, \mathrm{W}}^{j}=\frac{X_{\mathrm{US}, \mathrm{W}}^{j}}{G O_{\mathrm{US}}^{j}},
$$

where $X_{\mathrm{US}, \mathrm{W}}^{j}$ represents total U.S. trade flows of intermediate goods in sector $j$, and $G O_{\mathrm{US}}^{j}$ is gross output of the United States in sector $j$.

Equation (1) measures the share of U.S. production in sector $j$ that uses traded intermediate goods from the the world (in the case of import exposure) and the share of U.S. sales in sector $j$ that is exported to the world (in the case of export exposure). For industries that rely heavily on imported intermediate products, if the United States were to impose uniform tariffs across all sectors and trading partners, these industries would be impacted the most. If trading partners retaliated by increasing tariffs across all U.S. sectors, those industries most exposed to exports would be affected the most.

Panel A of Figure 1 plots the top five U.S. industries with the largest import exposure to the world. $\underline{5}$ These industries are Coke and petroleum, Motor vehicles and trailers, Other transport equipment, Basic metals, and Rubber and plastic products. For instance, the Coke and petroleum industry relies heavily on imports from Mining and quarrying and from Basic metals from Brazil, Mexico, and Canada. Motor vehicles and trailers relies on imports from the Motor vehicles and trailers industry in Germany, Japan, China, Canada, and Mexico. Panel B of Figure 1 plots the top five U.S. industries with the largest export exposure to the world. These are Other transport equipment, followed by Computer, electronic, and optical; Machinery and equipment, n.e.c; Electrical equipment; and Chemicals and pharmaceuticals.

\subsection{State-Level Trade Exposure}

Sectoral heterogeneity in trade exposure likely translates into state heterogeneity, as states differ in their sectoral composition of production. States that produce more in sectors heavily exposed to trade may be more impacted by changes in international trade policy. We construct a measure of state exposure to international trade by sector that combines sectoral 
Figure 1

\section{Sectoral Exposure of the United States to the World}

\section{A. U.S. sectoral import exposure to world}

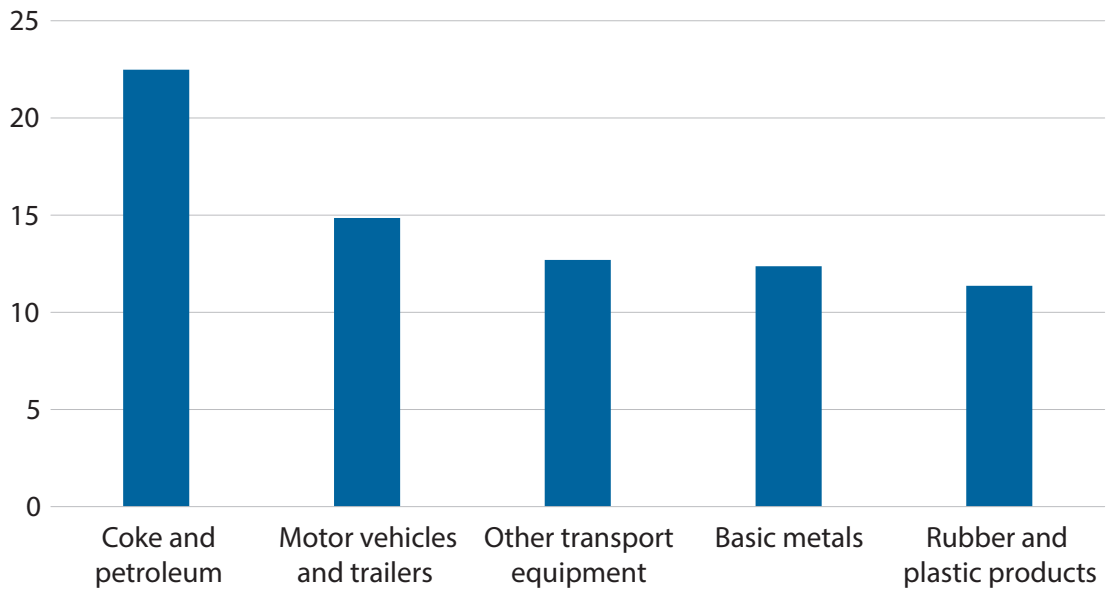

\section{B. U.S. sectoral export exposure to world}

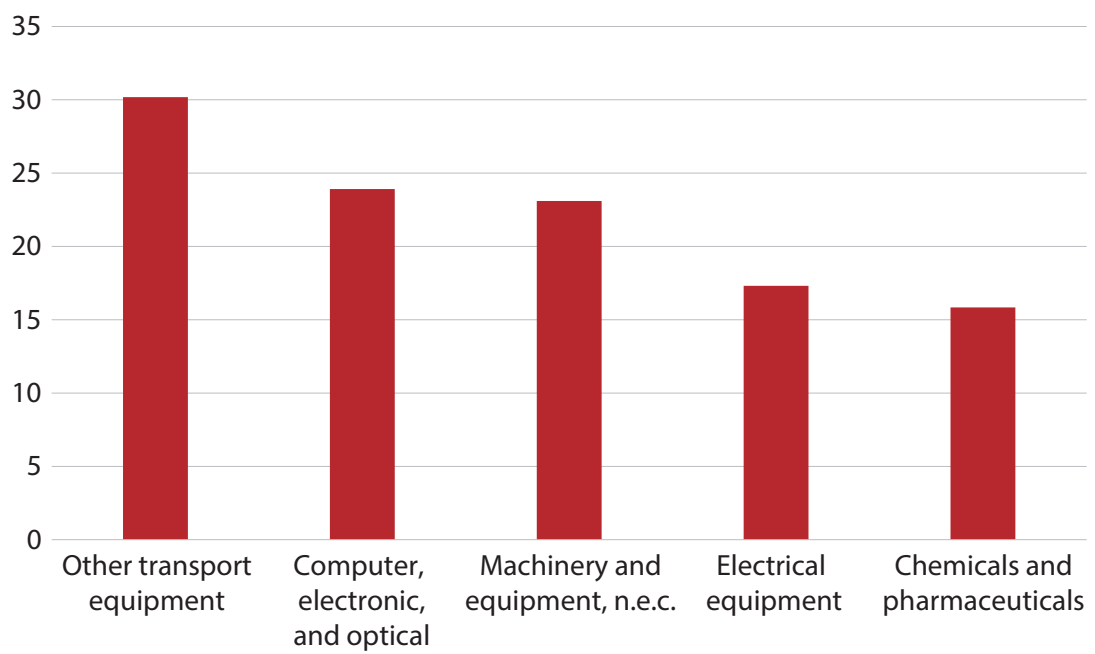

NOTE: This figure plots sectoral import and export exposure computed using equation (1) for the top five mostexposed sectors.

SOURCE: Authors' calculations. 


\section{Santacreu and Peake}

exposure from equation (1) with the sectoral composition of production of each U.S. state. In particular, state $s$ 's trade exposure to sector $j$ is computed as

$$
E_{\mathrm{US}, \mathrm{W}}^{j, s}=\frac{X_{\mathrm{US}, \mathrm{W}}^{j}}{G O_{\mathrm{US}}^{j}} \frac{V A^{j, s}}{\sum_{j} V A^{j, s}},
$$

where $\frac{V A^{j, s}}{\sum_{j} V A^{j, s}}$ is the value-added share of state $s$ in sector $j . \underline{6}$

The following are two contributing factors to state-sector exposure in equation (2):

(i) the initial exposure of each U.S. sector, $\frac{X_{\mathrm{US}, \mathrm{W}}^{j}}{G O_{\mathrm{US}}^{j}}$; and (ii) the value-added share of each state in that sector, $\frac{V A^{j, s}}{\sum_{j} V A^{j, s}}$.

Figure 2 plots the distribution of import exposure to the world across U.S. states for the top two sectors and the bottom two sectors based on their exposure to imports. Figure 3 does the same from the perspective of exports. Darker colors represent higher exposure to trade. Heat maps with the most-exposed sectors have darker colors on average, as we have imposed the scale of the bins to be the same across all sectors. The figures show that, within each sector, there is a lot of heterogeneity across U.S. states in their trade exposure, which is explained by the composition of production. If a state has a high value-added share in a particular sector, the state will be more exposed to changes in trade policy affecting that particular sector (and that state will have a darker color in the graph).

We start by documenting state-sector heterogeneity for import exposure. As we have shown previously, Coke and petroleum and Motor vehicles and trailers are the two sectors most exposed to imports from the world. Forestry, fishing, and logging and Furniture and other manufacturing are among the sectors least exposed. The state most exposed to imports in the Coke and petroleum industry is Louisiana, with 36 percent of its total value added being accounted for by this sector in 2014, followed by Hawaii (30 percent) and Montana (20 percent). In Louisiana, for instance, the extraction and processing of petroleum and natural gas became the state's largest industrial activity in the twentieth century. One of the largest manufacturers is Odyssea Marine, a gas and oil utility company. ${ }^{-}$In contrast, the state least exposed in this industry is Nebraska, with less than 0.1 percent of its value added in this industry, followed by South Dakota ( 0.1 percent) and Idaho ( 0.3 percent). For the Motor vehicles and trailers industry, the state most exposed is Michigan, for which the Motor vehicles and trailers industry comprised 43 percent of its total value added in 2014, followed by Tennessee (19 percent) and Kentucky (17 percent). Michigan has a long history of production in automobiles: Currently, it is home to both Chrysler and General Motors and acts as one of the top manufacturers of automobiles in the United States. In contrast, the state least exposed is Alaska, at a 0.02 percent value-added share, followed by Hawaii ( 0.03 percent) and Wyoming ( 0.1 percent). In the Forestry, fishing, and logging industry, the state most exposed is Maine, followed by Oregon and Florida. The state least exposed is Connecticut, followed by Ohio and Texas. In the Food, beverage, and tobacco industry, the state most exposed is Virginia, followed by Georgia and Hawaii. The state least exposed is Wyoming, followed by West Virginia and New Mexico. 


\section{Figure 2}

\section{Import Exposure by State and Sector}

\section{A. Coke and petroleum}

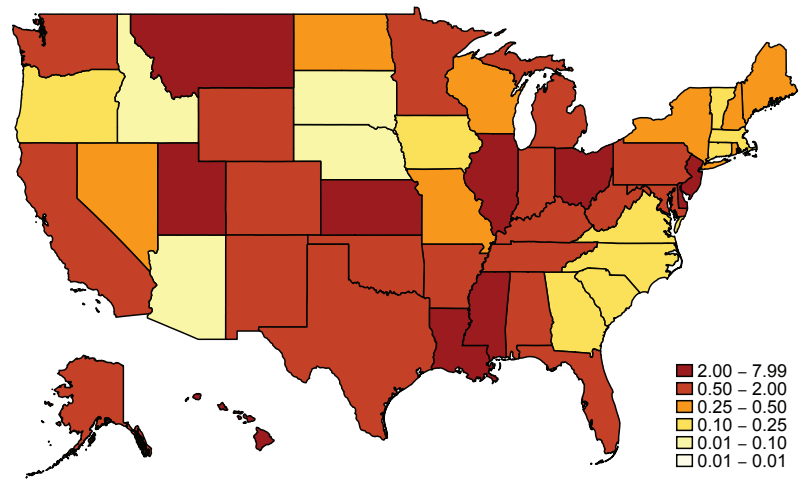

C. Forestry, fishing, and logging

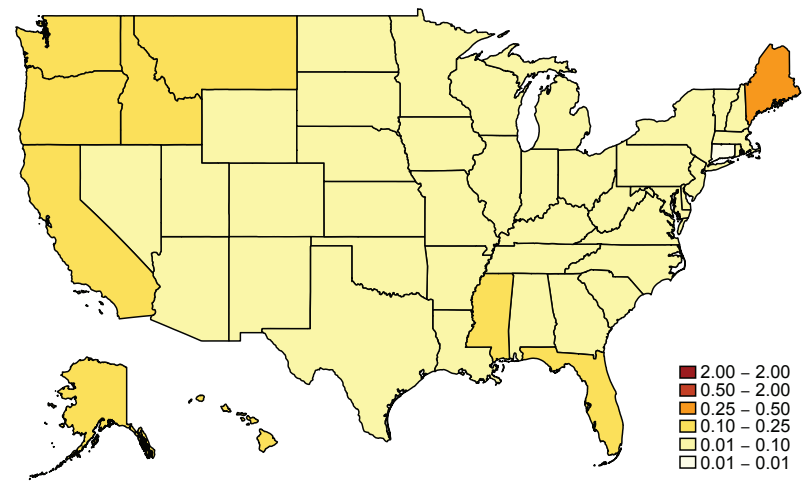

B. Motor vehicles and trailers

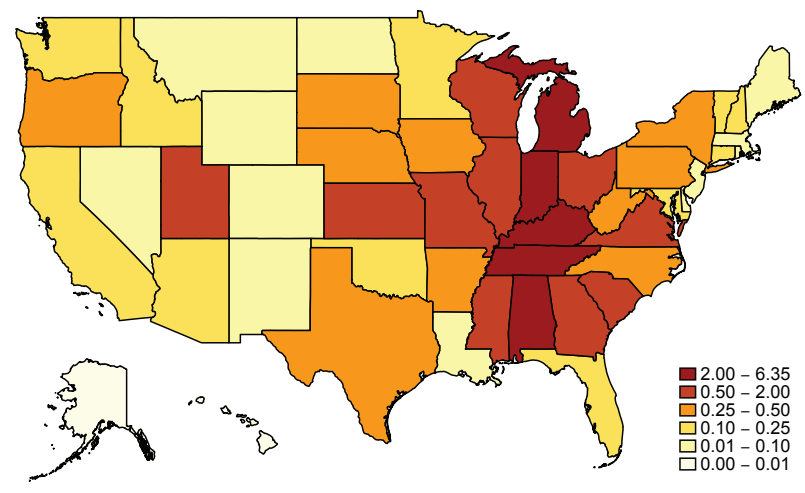

D. Furniture and other manufacturing

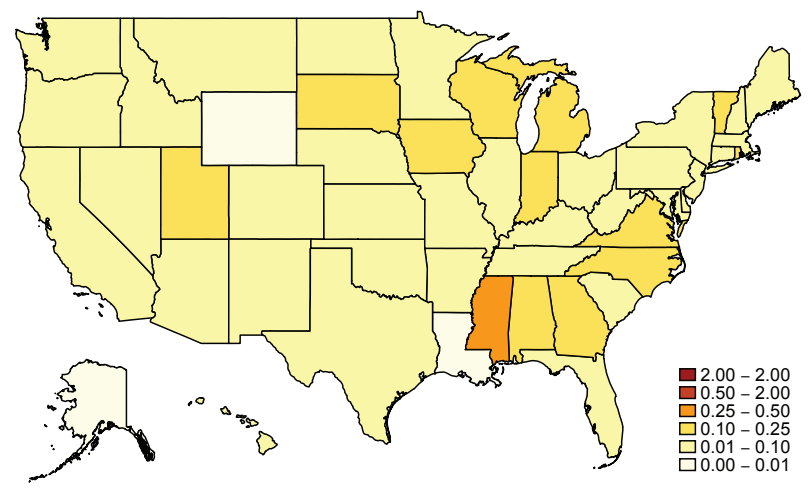

NOTE: The heat maps plot sector-state import exposure using equation (2) for the two sectors most exposed and the two sectors least exposed. Darker colors represent higher exposure. Bins have the same scale across all sectors.

SOURCE: Authors' calculations.

With regard to export exposure to the world, Other transport equipment and Computer, electronic, and optical are the sectors most exposed, whereas Other non-metallic mineral products and Wood and cork are the sectors least exposed. The state most exposed to the Other transport equipment industry is Washington, with 56 percent of its total value added in 2014 being accounted for by this sector, followed by Connecticut (25 percent) and Kansas (17 percent). Indeed, one of Washington's largest manufacturers is the aerospace engineering company Boeing. The state least exposed in this industry is Wyoming, with 0.07 percent of its value added in this industry, followed by Montana ( 0.09 percent) and Alaska ( 0.01 percent). For the Computer, electronic, and optical industry, the state most exposed is Oregon, with a 43 percent value-added share in this industry, followed by Massachusetts ( 33 percent) and California (27 percent). Major technology moguls such as Apple, Google, and Facebook are 


\section{Figure 3}

\section{Export Exposure by State and Sector}

\section{A. Other transport equipment}

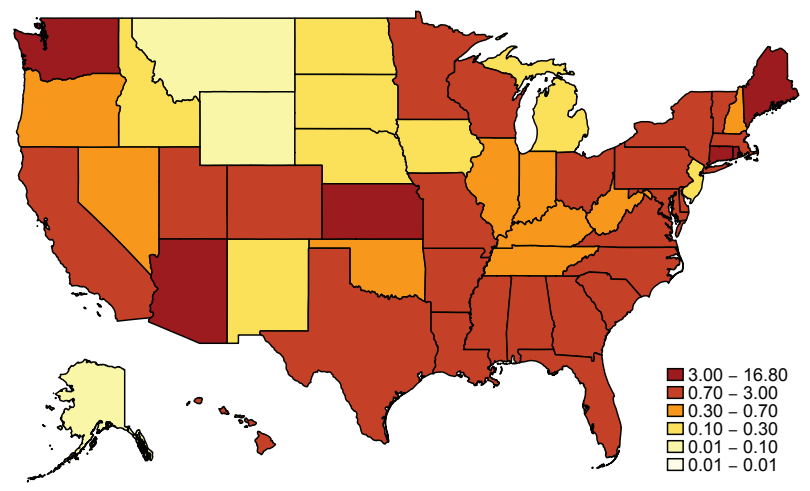

C. Other non-metallic mineral products

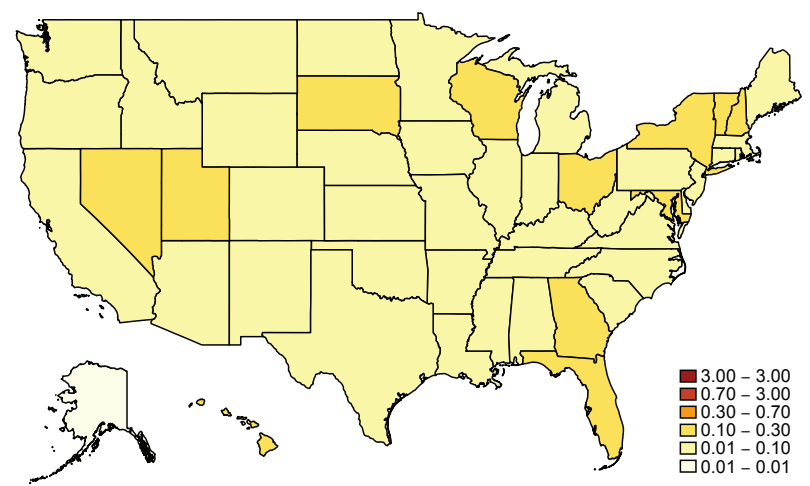

\section{B. Computer, electronic, and optical}

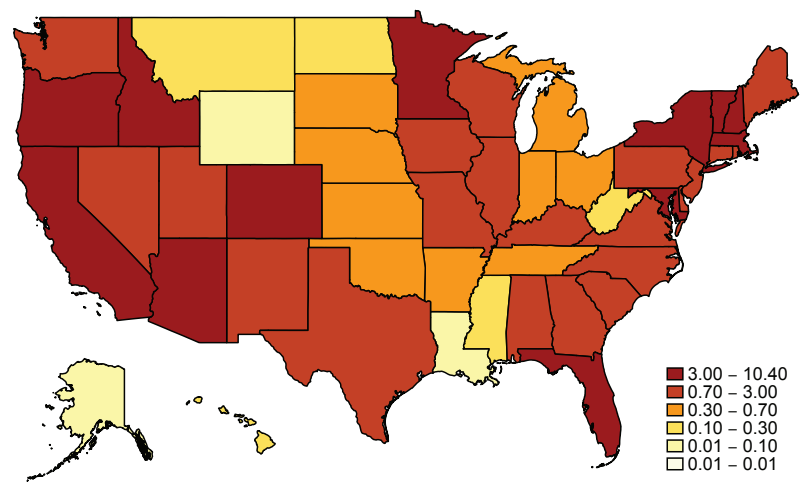

D. Wood and cork

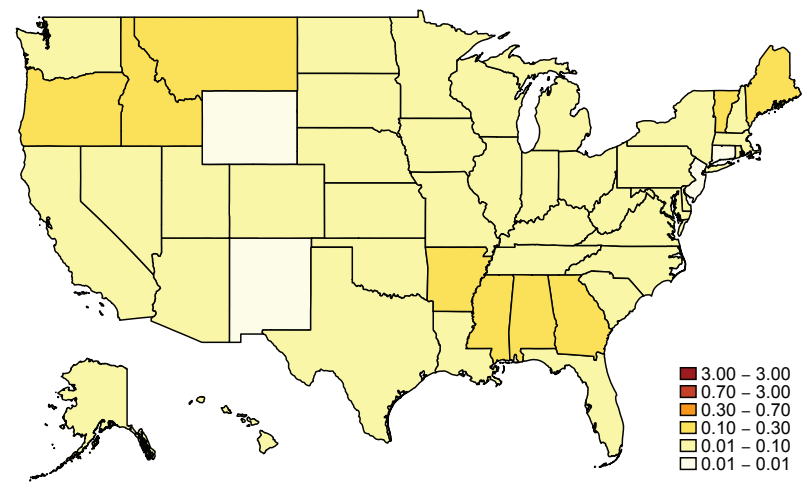

NOTE: The heat maps plot sector-state export exposure using equation (2) for the two sectors most exposed and the two sectors least exposed. Darker colors represent higher exposure. Bins have the same scale across all sectors.

SOURCE: Authors' calculations.

headquartered in California, bringing large-scale employment into the area and attracting a continuous stream of innovative companies. The state least exposed in this industry is Alaska, with a 0.09 percent value-added share, followed by Wyoming ( 0.3 percent) and Louisiana (0.3 percent). In Other non-metallic mineral products, the state most exposed is Hawaii, followed by Vermont and Florida. The state least exposed is Alaska, followed by Connecticut and Wyoming. In the Wood and cork industry, the state most exposed is Oregon, followed by Maine and Vermont. The state least exposed is Wyoming, followed by New Mexico and Connecticut.

Figure 4 shows patterns of specialization and diversification of production for a sample of U.S. states. Louisiana, Michigan, Washington, and California specialize in highly exposed sectors. Wyoming, instead, specializes in Mining and quarrying, which is not very exposed to trade. We also observe sectors that are very diversified, such as Maine. 


\section{Figure 4}

\section{Value-Added Shares Across Industries}

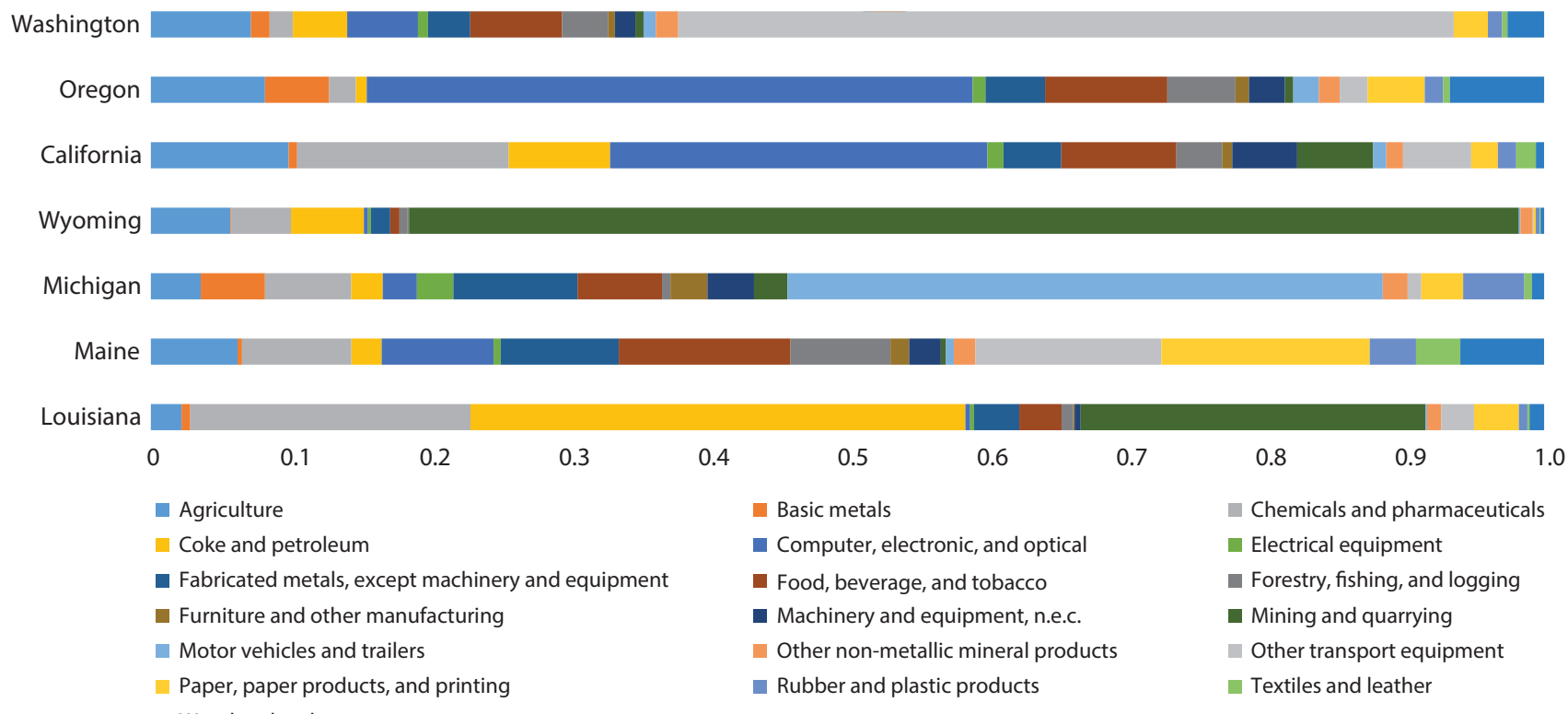

NOTE: The figure shows value-added shares across industries for Washington, Oregon, California, Wyoming, Michigan, Maine, and Louisiana. Darker colors represent industries that are more heavily imported and exported by the United States, and subsequently more exposed to international trade.

SOURCE: Authors' calculations.

Analyzing exposure levels of states and sectors is crucial, as states producing a significant portion of their value added in industries that are heavily exposed to trade will be more affected by changes in trade policy. Next, we construct a measure of total trade exposure at the state level, $E_{\mathrm{US}, \mathrm{W}}^{s}$, as

$$
E_{\mathrm{US}, \mathrm{W}}^{s}=\sum_{j} \frac{X_{\mathrm{US}, \mathrm{W}}^{j}}{G O_{\mathrm{US}}^{j}} \frac{V A^{j, s}}{\sum_{j} V A^{j, s}} .
$$

If a state $s$ specializes in a sector $j$ that is heavily exposed to international trade, then that state will be more exposed to changes in trade policy. Figure 5 depicts total trade exposure to both imports (Panel A) and exports (Panel B) between the United States and the world.

As for imports, the states most exposed are Louisiana and Michigan, followed by Hawaii, Washington, and Ohio. The states least exposed are North Dakota and Alaska, followed by New Mexico, Wyoming, and Idaho. Louisiana's exposure is a combination of two factors. First, it is one of the main producers in the Coke and petroleum sector, which is the sector most exposed to imports (see Figure 1). Second, Coke and petroleum accounts for around 36 percent of Louisiana's total value-added share. Similarly, Michigan is one of the top U.S. producers in the Motor vehicle and trailers industry, which accounts for 43 percent of its total value added. 


\section{Figure 5}

\section{State-Level Trade Exposure}

A. State import exposure

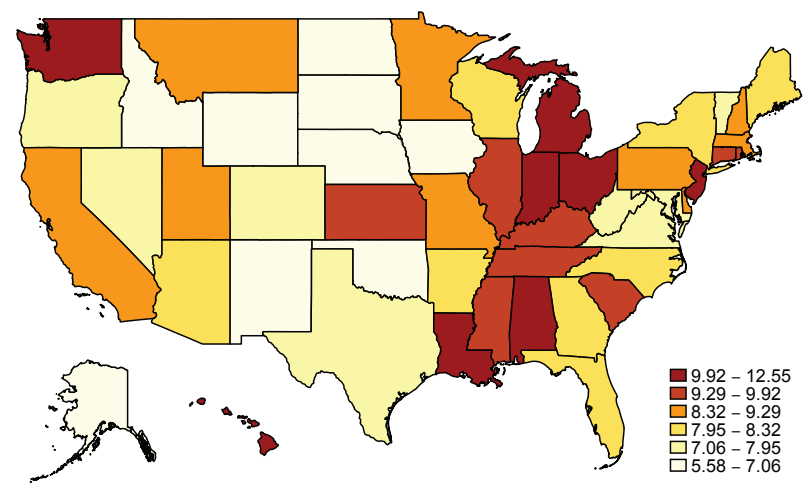

B. State export exposure

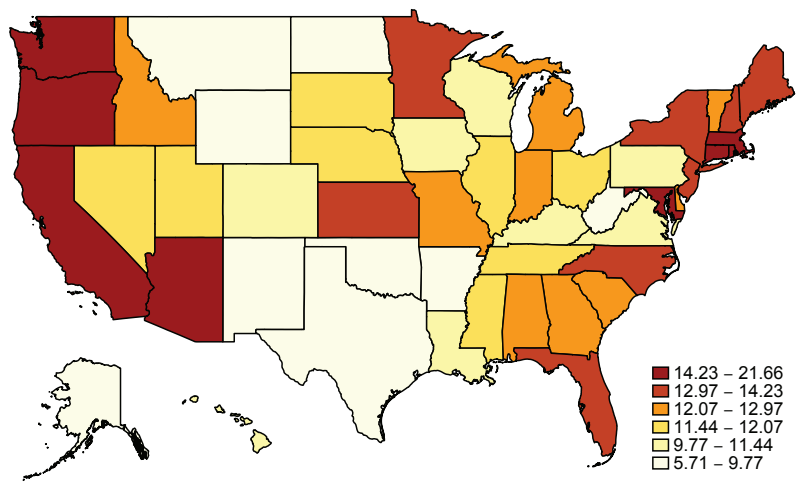

NOTE: The heat maps plot state import and export exposure using equation (3). Darker colors reflect states most exposed. SOURCE: Authors' calculations.

Other states that are highly exposed, such as Hawaii, Washington, and Ohio, are highly specialized in industries in which the United States imports heavily. For example, Hawaii and Ohio are among the top producers in the Coke and petroleum industry, alongside Louisiana, and Washington is heavily specialized in the Other transport equipment industry, which was the third sector most exposed to imports in 2014. The states least exposed are North Dakota and Alaska. Alaska specializes in Mining and quarrying, which accounts for 87 percent of its total value added. North Dakota specializes in Mining and quarrying and Agriculture, which together account for 85 percent of its total value added. These industries are among the least exposed to imports in 2014 (see Figure A1 in the appendix).

For exports, the states most exposed are Washington, Connecticut, Massachusetts, Arizona, and Rhode Island, followed by Oregon and California. The states least exposed are Alaska, Wyoming, North Dakota, Oklahoma, and New Mexico. Washington specializes in Other transport equipment; Connecticut and Massachusetts specialize in Computer, electronic, and optical products and Chemicals and pharmaceuticals; Arizona specializes in Computer, electronic, and optical and Other transport equipment; and Rhode Island specializes in Machinery and equipment, n.e.c. and Other transport equipment. These sectors are heavily exposed to exports. Alaska and Wyoming specialize in Mining and quarrying, of which exports are not very exposed to the world (see Figure A1 in the appendix).

\subsection{Trade Exposure and Economic Activity}

In this section, we exploit the state-level heterogeneity in exposure of imports and exports documented in Section 2.2 and relate it to differences in economic activity across U.S. states. The current U.S. administration began talking about increasing tariffs in October 2017 after 
the U.S. International Trade Commission found that imports of certain products were negatively impacting U.S. producers of such goods. These announcements increased uncertainty in the tradable sectors. If firms reacted to this uncertainty by adjusting their employment and production decisions, states that were most exposed to imports would be impacted the most. Talks about retaliation by main trading partners of the United States would instead have a bigger impact on states that were most exposed to exports.

We follow the approach of Mian and Sufi (2009) who exploit within-county variation in credit growth to explain cross-state variations in income growth. We use their methodology to exploit cross-state variation in trade exposure and relate it to cross-state variation in output growth and employment growth. The idea is as follows: Consider two U.S. states-State A is very exposed to trade and State B is less exposed. An announcement of increases in tariffs will have a disproportionately larger impact on State A than on State B.

To analyze the effect on the U.S. economy, we use state-level quarterly data for employment and output for the three main broad industries considered in our analysis (Agriculture, Mining and quarrying, and Furniture and other manufacturing). Employment data are from the Bureau of Labor Statistics (BLS) for all goods-producing industries; output data are from the Bureau of Economic Analysis (BEA) — quarterly GDP data by state in real millions of 2012 chained U.S. dollars-for Agriculture, Mining and quarrying, and Furniture and other manufacturing. For both employment and output, we compute quarterly growth rates from 2018:Q1 to 2019:Q1.

Panels A and B of Figure 6 plot the correlation between the initial state-level import exposure and the following: (i) state-level GDP growth from 2018:Q1-2019:Q1 (Panel A) and (ii) state-level employment growth from 2018:Q1-2019:Q1 (Panel B). We find that states more exposed to imports experienced lower increases in GDP growth (a correlation of -0.18) and even lower increases in employment growth (a correlation of -0.45$).^{\underline{9}}$

Panels $\mathrm{C}$ and $\mathrm{D}$ of Figure 6 plot the correlation between the initial state-level export exposure and our measures of economic activity. We find that states more exposed to exports experienced lower increases in GDP growth (a correlation of -0.20) and even lower increases in employment growth (a correlation of -0.23).

The results presented so far suggest the following: (i) There is a negative correlation between initial trade exposure and economic activity across U.S. states; (ii) cross-state variation in trade exposure correlates more negatively with employment growth than it does with output growth; and (iii) import exposure seems to have had a stronger impact on economic outcomes than has export exposure. These points could reflect that firms operating in states that are more exposed to trade adjusted their employment and production decisions more after announcements of tariff increases by the United States.

Finally, we construct a measure of state total trade exposure as the sum of import and export trade exposures. This measure shows which states would be more impacted by trade policy if the United States imposed a uniform tariff across every trading partner and sector and, simultaneously, all trading partners retaliated by increasing tariffs uniformly across every U.S. sector. Panels E and F of Figure 6 plot the correlation between this measure and (i) statelevel GDP growth from 2018:Q1-2019:Q1 (Panel E) and (ii) state-level employment growth 


\section{Figure 6}

\section{Trade Exposure to World and Economic Activity, 2018:Q1-2019:Q1}

\section{A. GDP growth}

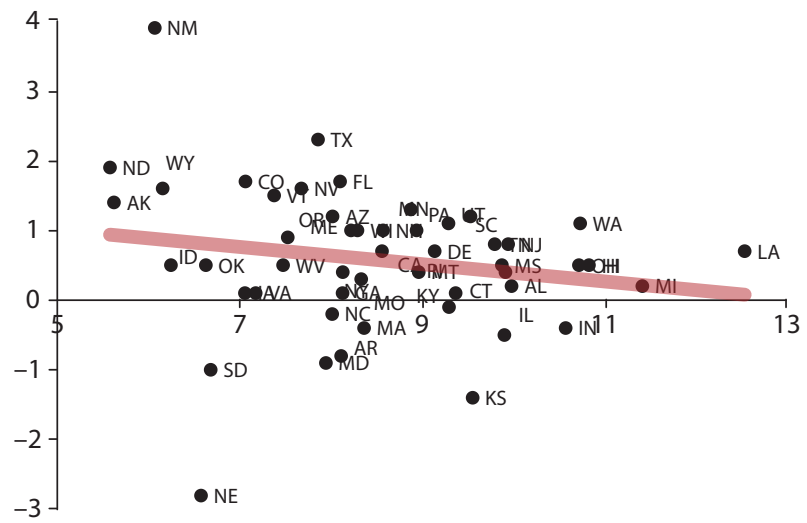

Import exposure to world

\section{GDP growth}

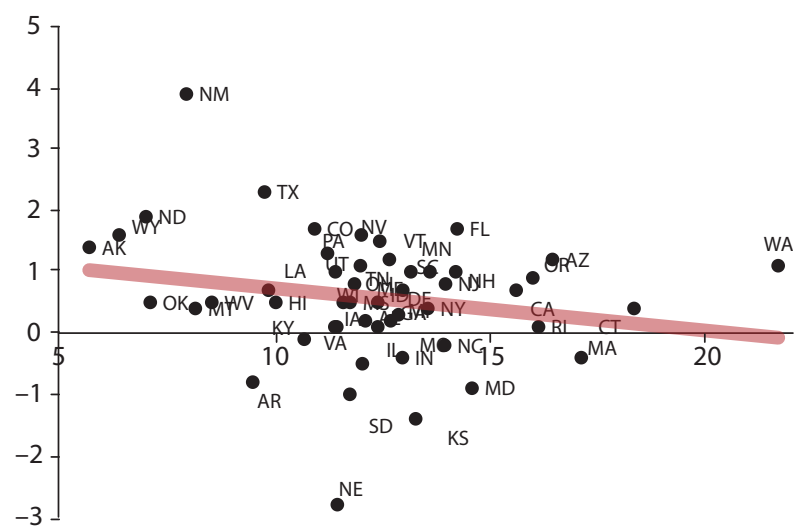

Export exposure to world

E. GDP growth

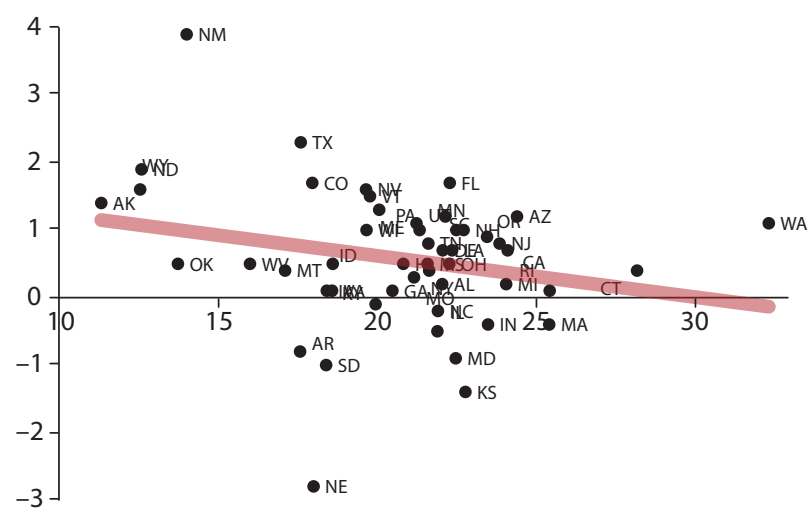

Total exposure to world
B. Employment growth

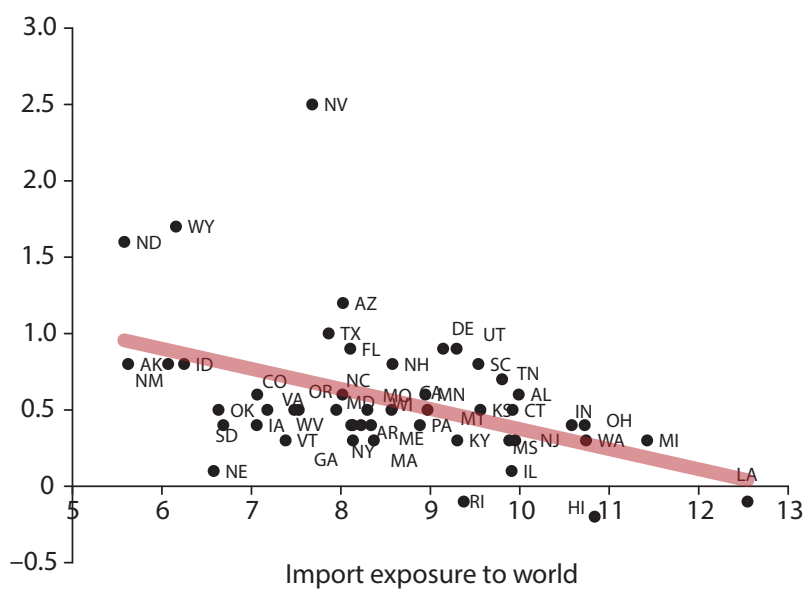

D. Employment growth

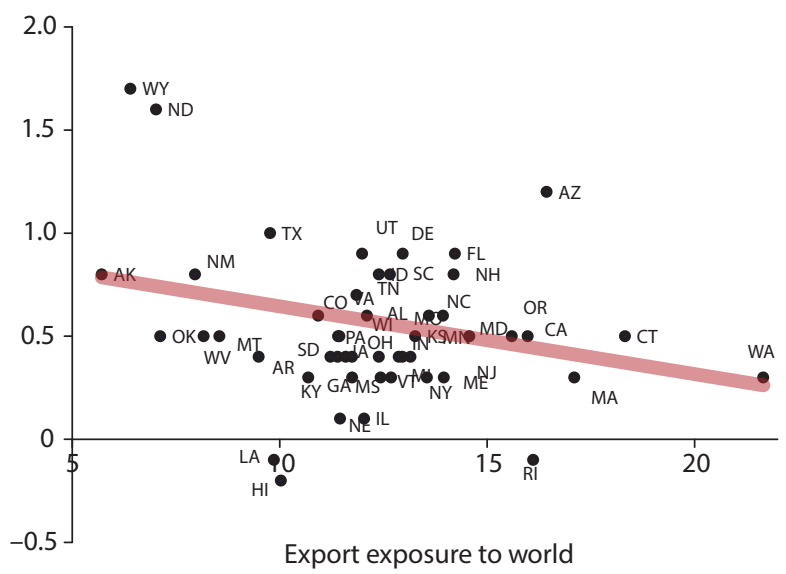

F. Employment growth

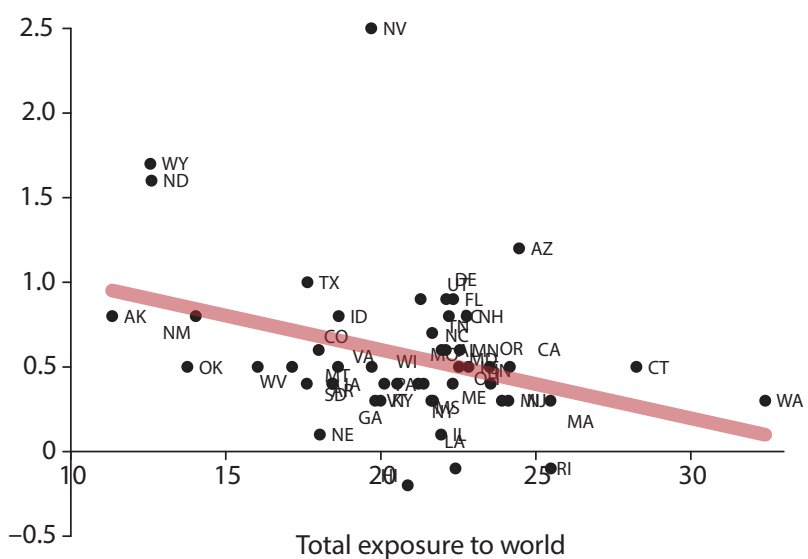

NOTE: This figure plots, in the $x$-axis, heterogeneity in import exposure (Panels $A$ and $B$ ), export exposure (Panels $C$ and $D$ ), and total exposure (Panels E and F), and relates them to GDP growth and employment growth for 2018:Q1-2019:Q1 (y-axis).

SOURCE: Authors' calculations. 
from 2018:Q1-2019:Q1 (Panel F). We observe a negative correlation between total trade exposure and economic activity. Once again the correlation is more negative in the case of employment than in the case of output growth (i.e., -0.35 vs. -0.23 , respectively).

Our results suggest that states that were more exposed to trade experienced worse economic outcomes in terms of production and employment. Obviously, there are economic forces other than trade exposure that could be driving heterogeneous adjustments in employment and production across U.S. states. Figure 6 does not imply any causality effects. However, the strong negative correlation between the variables suggests that initial trade exposure could have played an important role in those adjustments.

\section{U.S.-CHINA TRADE WAR}

In the previous section, we constructed a measure of trade exposure in which we did not use any data on current tariffs. In this section, we focus on one particular episode, the U.S.China trade war, and use actual data on tariffs. Specifically, we evaluate the impact of the current increase of U.S. tariffs on imports from China, and the subsequent retaliatory measures imposed by the Chinese government on American products. Given the current trade tensions between the United States and China, it is important to narrow our analysis to focus on trade between these two countries. Furthermore, China accounts for the largest share of U.S. exports under retaliatory tariffs among the main U.S. trading partners (China, Canada, Mexico, and the EU). 10

\subsection{Tariff Data}

Tariff data in the context of the U.S.-China trade war are from the Iowa State University Center for Agricultural and Rural Development. We look at recent tariff increases by the United States and retaliatory tariffs by China. The database provides tariff data aggregated to 6-digit Harmonized System (HS) code commodity levels. We then classify the products into each of our 19 sectors and compute, for each sector, simple averages of tariff rates across the different 6-digit HS goods that belong to that sector. Figure 7 plots the top 10 sectors with the largest U.S. tariff increases (Panel A) and the largest retaliatory Chinese tariff increases (Panel B). The largest tariff increases imposed by the United States are on the Electrical equipment industry ( 23 percent), followed by the Other transport equipment industry (just under 23 percent) and the Machinery and equipment, n.e.c. industry (21 percent). China has placed the highest tariffs on the Coke and petroleum industry (20 percent), followed by the Basic metals industry (13 percent) and, finally, the Food, beverage, and tobacco industry (11 percent). China's retaliatory tariffs are about 10 percent on Furniture and other manufacturing and Agriculture. $\underline{11}$

\subsection{Sectoral Trade Exposure to China}

We now compute a measure of initial sectoral trade exposure to China. This measure differs slightly from the one used in the previous section because we now keep track of the 
Figure 7

\section{Tariff Levels}

A. Tariffs, U.S.

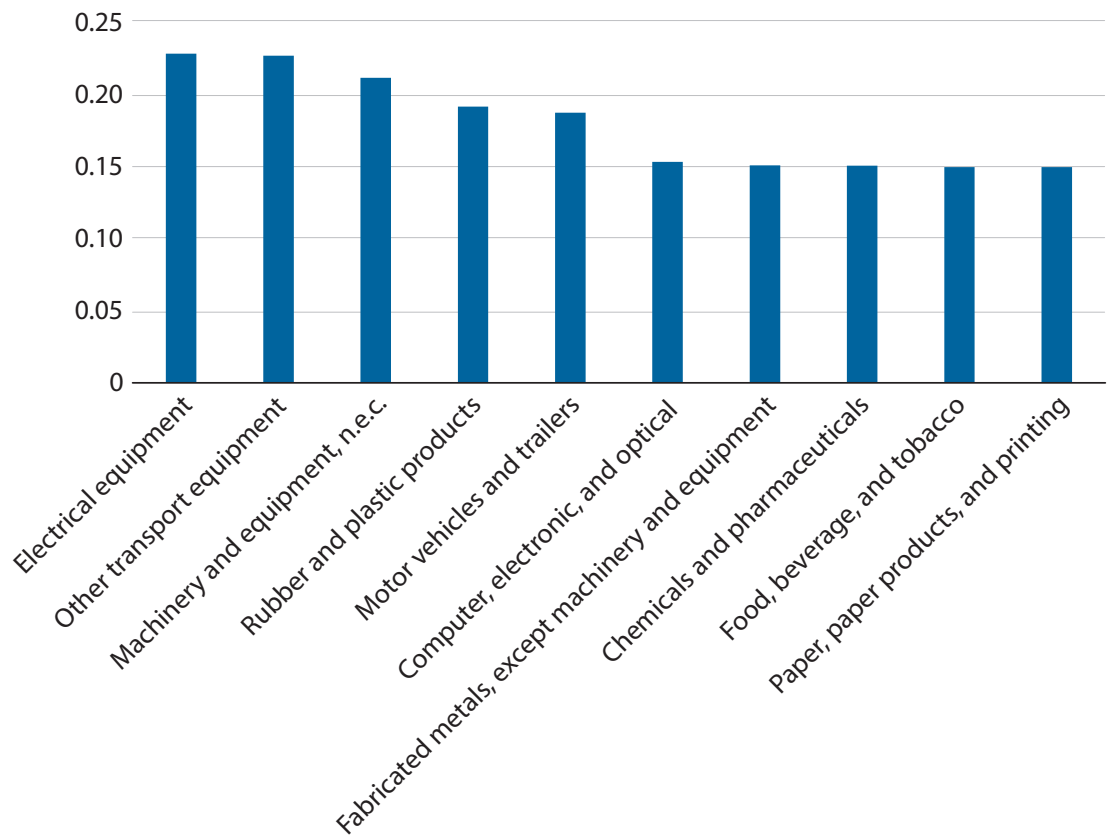

\section{B. Retaliatory tariffs, China}

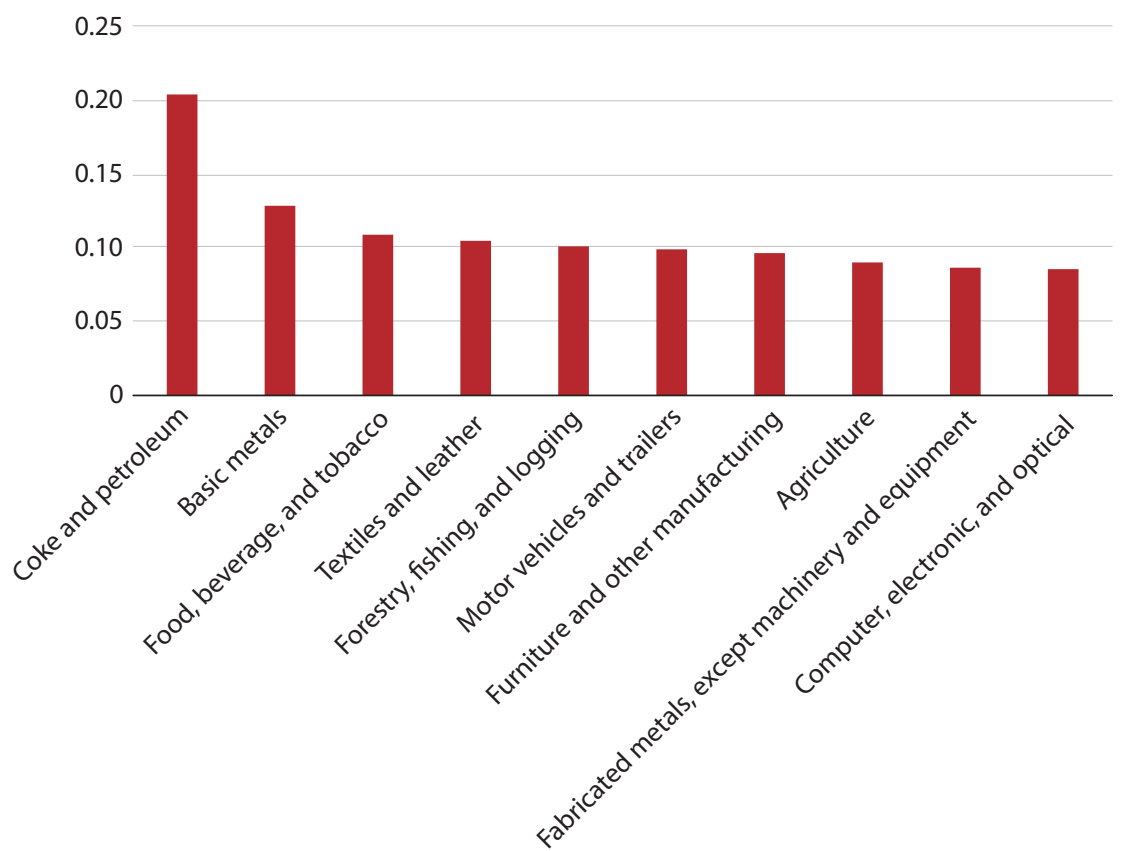

NOTE: The bar charts plot recent tariff changes for the top 10 industries most affected by tariffs, both U.S. tariffs and retaliatory China tariffs.

SOURCE: Authors' calculations. 


\section{Figure 8}

\section{U.S. Sectoral Exposure to China}

\section{A. U.S. imports from China}

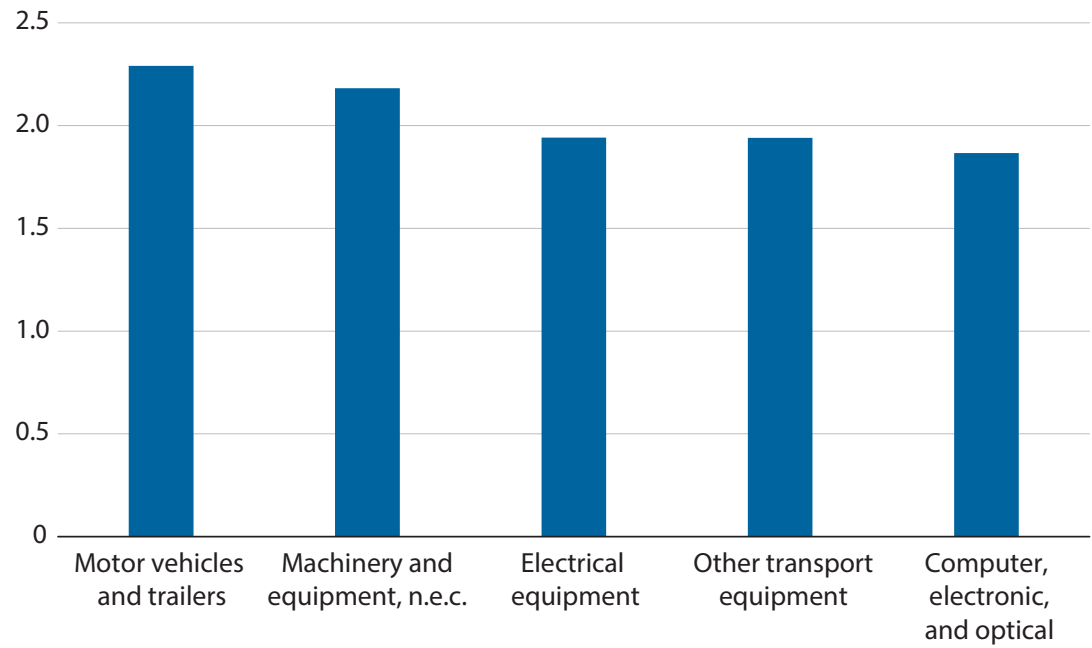

\section{B. U.S. exports to China}

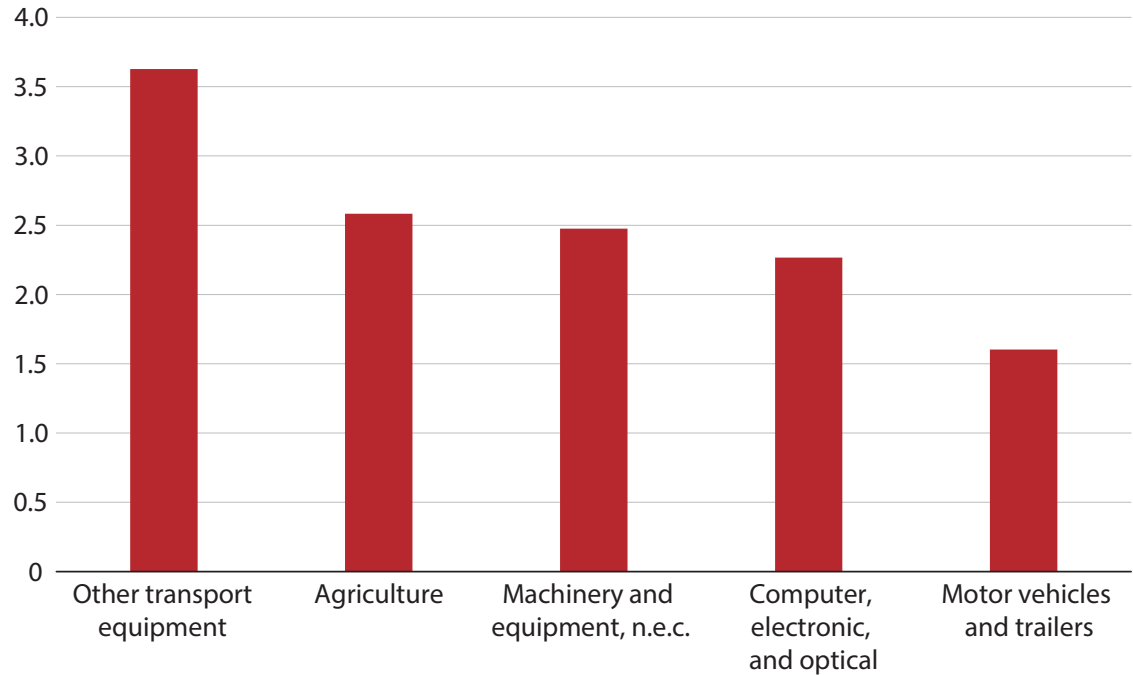

NOTE: This figure plots sectoral import and export exposure computed using equations (4) and (5) for the top five most-exposed sectors.

SOURCE: Authors' calculations. 


\section{Santacreu and Peake}

specific sectors affected by actual tariff increases. Specifically, sector $j$ 's import exposure to China is computed as

$$
M_{\mathrm{US}, \text { China }}^{j}=\frac{\sum_{k} M_{\mathrm{US}, \mathrm{China}}^{j k} \tau^{k}}{G O_{\mathrm{US}}^{j}},
$$

where $\mathrm{M}_{\mathrm{US} \text {,China }}^{j k}$ represents the United States' sector $j$ imports from China's sector $k$, and $\Delta \tau_{k}$ is the actual increase in tariffs imposed by the United States onto Chinese products from sector $k$.

Sector $j$ 's export exposure to China is computed as

$$
X_{\mathrm{US}, \text { China }}^{j}=\frac{X_{\mathrm{US}, \text { China }}^{j} \tau^{j}}{G O_{\mathrm{US}}^{j}},
$$

where $\mathrm{X}_{\mathrm{US} \text {,China }}^{j}$ represents the United States' sector $j$ exports to China, and $\Delta \tau^{j}$ is the actual increase in retaliatory tariffs by China on U.S. products from sector $j$.

Figure 8 plots the five industries with the largest sectoral trade exposure to China. $\frac{12}{1}$ The five industries most exposed to imports (Panel A) are Motor vehicles and trailers; Machinery and equipment, n.e.c.; Electrical equipment; Other transport equipment; and Computer, electronic, and optical. $\underline{13}$ Note that this measure exploits information from the input-output structure of the U.S. economy and information on actual tariff rate increases. It captures that sectors that import more from sectors experiencing large U.S. tariff increases are more exposed. For instance, the Coke and petroleum sector was very exposed to imports from the world, but not very exposed to imports from China. This is because the Coke and petroleum industry in the United States imports 92 percent of its intermediate inputs from the Mining and quarrying industry, which is not subject to large U.S. tariffs. Because we did not use actual tariff data in our measure of import exposure to the world, the fact that this industry relies heavily on imports-despite being from a sector where the United States has not imposed high tariffswas sufficient to generate high exposure. In contrast, the Motor vehicles and trailers industry imports 53 percent of its intermediate inputs from that same industry from other countries, which makes this industry bear the brunt of the largest U.S. tariffs. The five industries most exposed to exports (Panel B of Figure 8) are Other transport equipment; Agriculture; Machinery and equipment, n.e.c.; Computer, electronic, and optical; and Motor vehicles and trailers.

\subsection{State Trade Exposure to China}

We now construct a measure of exposure to trade with China by sector and state that combines sectoral heterogeneity at the U.S. level—from equations (4) and (5) - with heterogeneity in the composition of production across U.S. states. Figure 9 plots the state distribution of import exposure to China for the two most- and least-exposed sectors. Figure 10 does the same from the perspective of exports.

With regard to import exposure to China, Motor vehicles and trailers and Machinery and equipment, n.e.c. are the sectors most exposed. In contrast, the Mining and quarrying and the Forestry, fishing, and logging industries are among the industries least exposed in our sample. The state most exposed to imports from China in Motor vehicles and trailers is Michigan, followed by Tennessee and Kentucky. In contrast, the state least exposed in this 


\section{Figure 9}

\section{U.S. Import Exposure to China, by State and Sector}

A. Motor vehicles and trailers

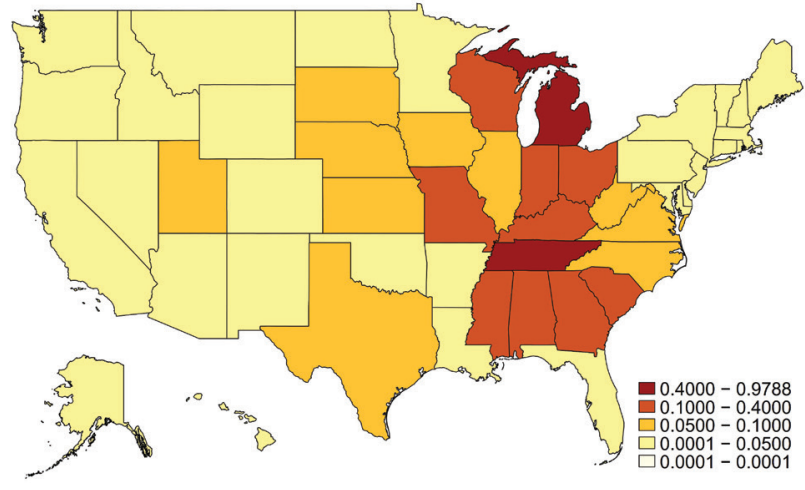

C. Mining and quarrying

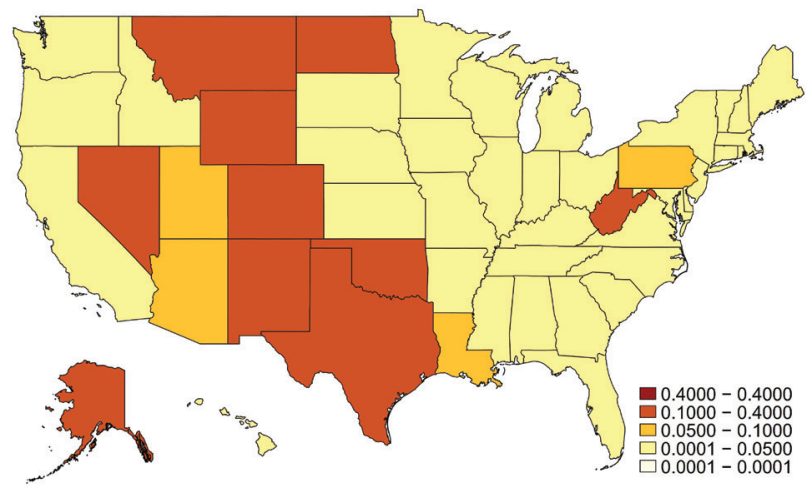

B. Machinery and equipment, n.e.c.

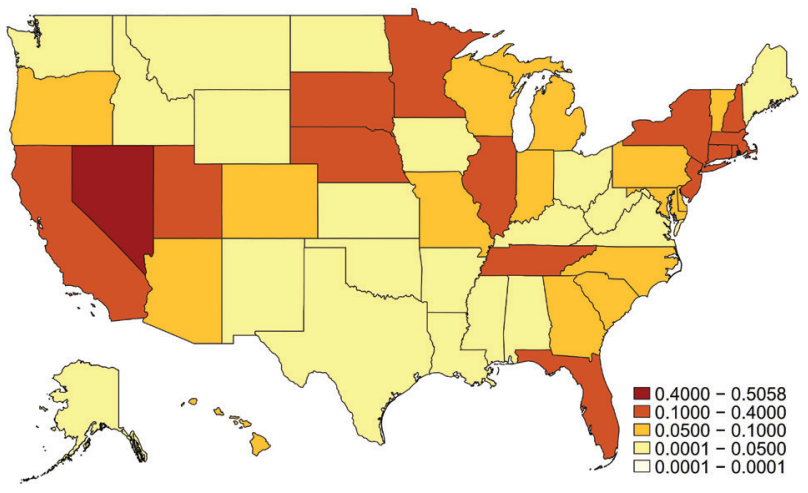

D. Forestry, fishing, and logging

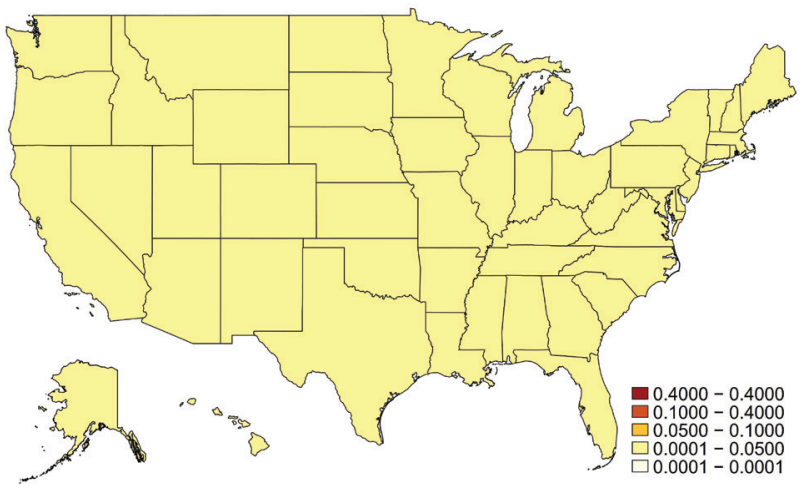

NOTE: The heat maps plot sector-state import exposure to China for the two sectors most exposed and the two sectors least exposed. Darker colors represent higher exposure. Bins have the same scale across all sectors.

SOURCE: Authors' calculations.

industry is Alaska, followed by Hawaii and Wyoming. For Machinery and equipment, n.e.c., the state most exposed is Nevada, for which this industry comprised 23 percent of the state's total value added in 2014, followed by Rhode Island (14 percent) and South Dakota (11 percent). In contrast, the states least exposed are Wyoming, Alaska, and North Dakota.

The industries least exposed to imports from China are Mining and quarrying and Forestry, fishing, and logging. In the Mining and quarrying industry, the state most exposed is Alaska, with 87 percent of its total value added in that sector, followed by Wyoming ( 80 percent) and New Mexico (68 percent). In the Forestry, fishing, and logging industry, the state most exposed is Maine, followed by Oregon and Florida.

With regard to export exposure to China, Other transport equipment and Agriculture are the sectors most exposed to exports, while Other non-metallic mineral products and Coke 


\section{Figure 10}

\section{U.S. Export Exposure to China, by State and Sector}

\section{A. Other transport equipment}

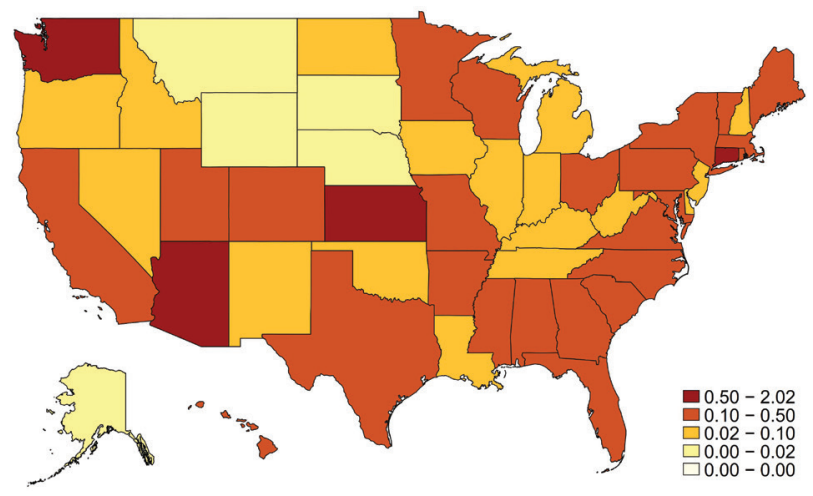

\section{Other non-metallic mineral products}

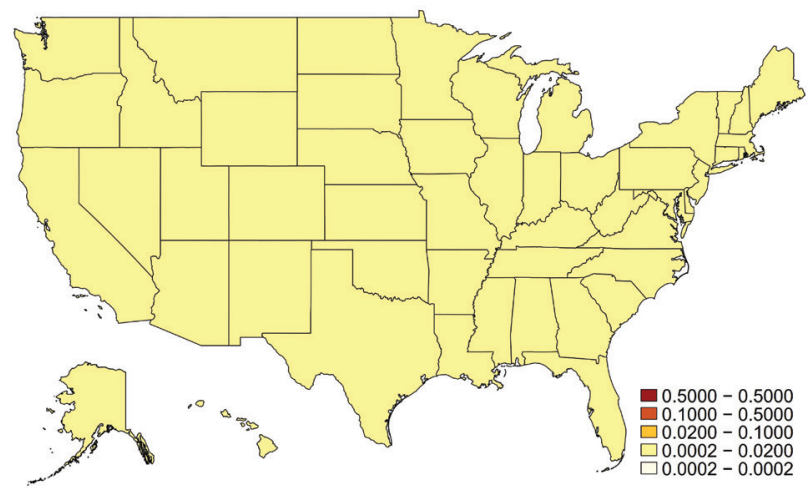

B. Agriculture

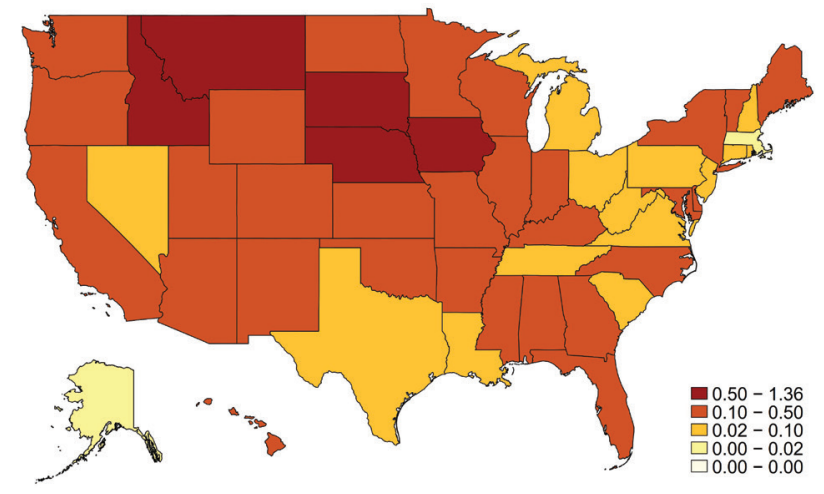

\section{Coke and petroleum}

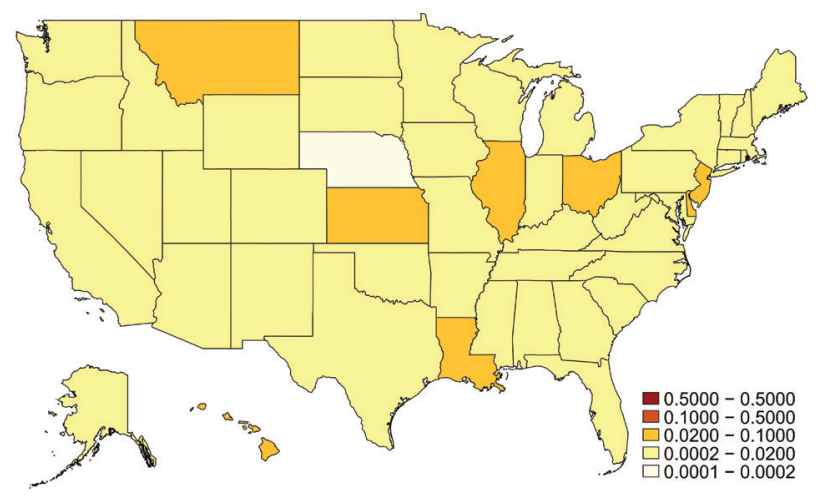

NOTE: The heat maps plot sector-state export exposure to China for the two sectors most exposed and the two sectors least exposed. Darker colors represent higher exposure. Bins have the same scale across all sectors.

SOURCE: Authors' calculations.

and petroleum are the sectors least exposed. The states most exposed to Other transport equipment are Washington, Connecticut, and Kansas. The states least exposed in this industry are Wyoming, Montana, and Alaska. For the Agriculture industry, the states most exposed are South Dakota, Nebraska, and Iowa. South Dakota is a large producer of crops, such as wheat, corn, and soybeans, often ranking within the top 10 national producers of certain crops. $\underline{14}$ The state least exposed in this industry is Alaska, followed by Massachusetts and Rhode Island. The industries least exposed to exports are Other non-metallic mineral products and Coke and petroleum. In the Other non-metallic mineral products industry, the state most exposed is Hawaii, followed by Vermont and Florida. The state least exposed in this industry is Alaska, followed by Connecticut and Wyoming. In the Coke and petroleum industry, the state most exposed is once again Louisiana, followed by Hawaii and Montana; the state least exposed is Nebraska, followed by South Dakota and Idaho. 


\section{Figure 11}

\section{United States' Trade Exposure to China}

\section{A. State import exposure}

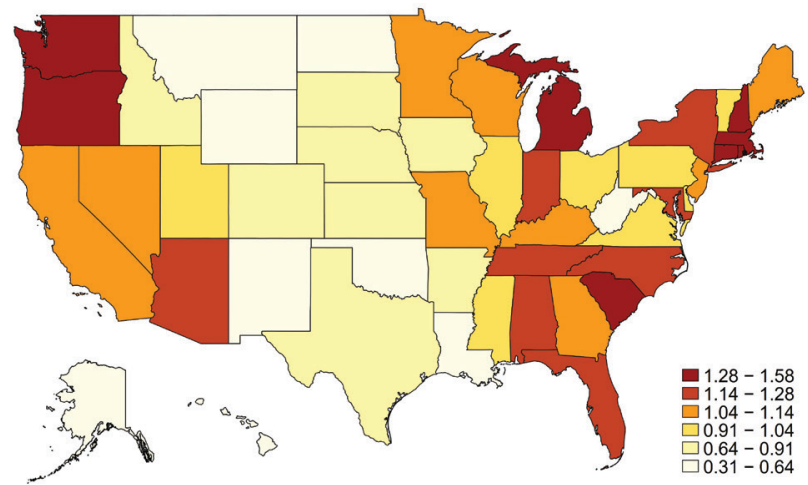

B. State export exposure

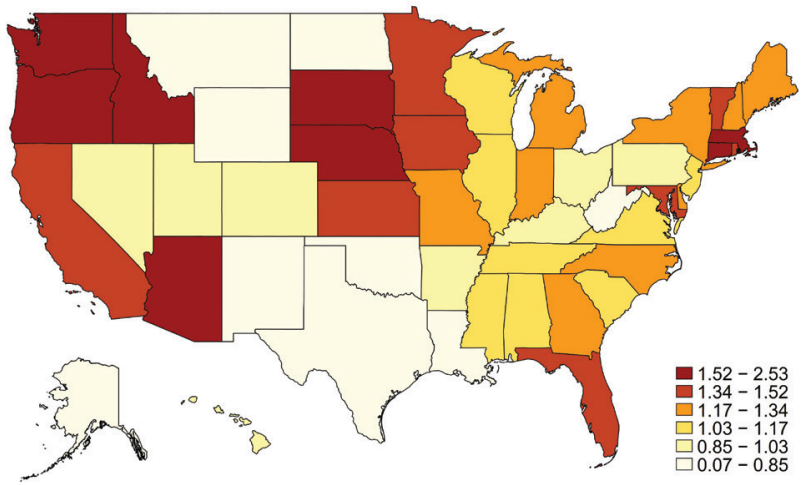

NOTE: The heat maps plot U.S. import and export exposure to China. Darker colors reflect states most exposed.

SOURCE: Authors' calculations.

Next, we compute a measure of state trade exposure using equation (3). Panel A of Figure 11 shows that the state most exposed to imports from China is Michigan, followed by Connecticut, Washington, Massachusetts, and Rhode Island. The states least exposed are Alaska, Wyoming, Montana, North Dakota, and Oklahoma. As mentioned previously, Alaska and Wyoming specialize in Mining and quarrying, which accounts for very little of the U.S. imports from China. 15 Panel B of Figure 11 shows that the states most exposed to exports to China are Washington, South Dakota, Connecticut, Nebraska, and Arizona. $\frac{16}{}$ The state least exposed is Alaska, followed by Wyoming, Oklahoma, West Virginia, and, finally, New Mexico.

\subsection{Trade Exposure to China and U.S. Economic Activity}

In this section, we exploit cross-state variation in trade exposure to China and relate it to differences in economic activity across U.S. states. The results are plotted in Figure 12 for import exposure (Panels A and B), export exposure (Panels C and D), and total exposure (Panels $\mathrm{E}$ and F). We find that, as before, there is a negative correlation-albeit a weaker one than in the case of exposure to the world-between our measures of trade exposure to China and both output growth and employment growth. However, in contrast to the results in Section 2.3, we find the following: (i) This correlation is lower with export exposure than it is with import exposure to China. That is, retaliatory tariffs seem to have had a bigger impact on U.S. economic activity. For instance, in the case of output growth, the correlation with import exposure and export exposure is -0.18 and -0.39 , respectively. In the case of employment growth, these correlations are -0.18 and -0.27 , respectively. And (ii) the correlation with output growth is lower than it is with employment growth. For instance, in the case of total exposure, these correlations are -0.33 and -0.25 , respectively. $\frac{17}{}$ 
Figure 12

Trade Exposure to China and Economic Activity, 2018:Q1-2019:Q1

A. GDP growth

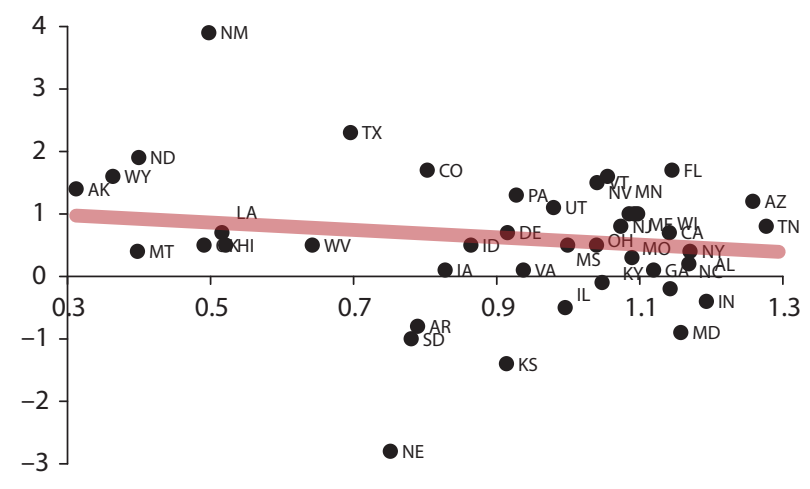

Import exposure to China

\section{GDP growth}

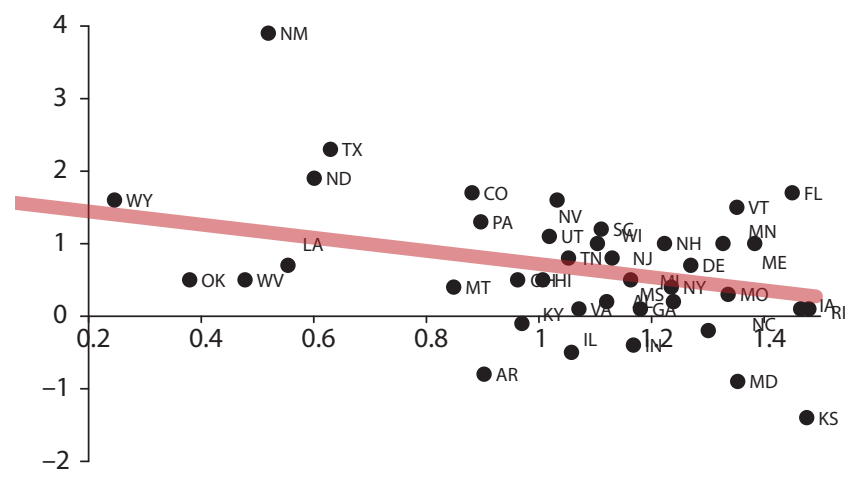

Export exposure to China

E. GDP growth

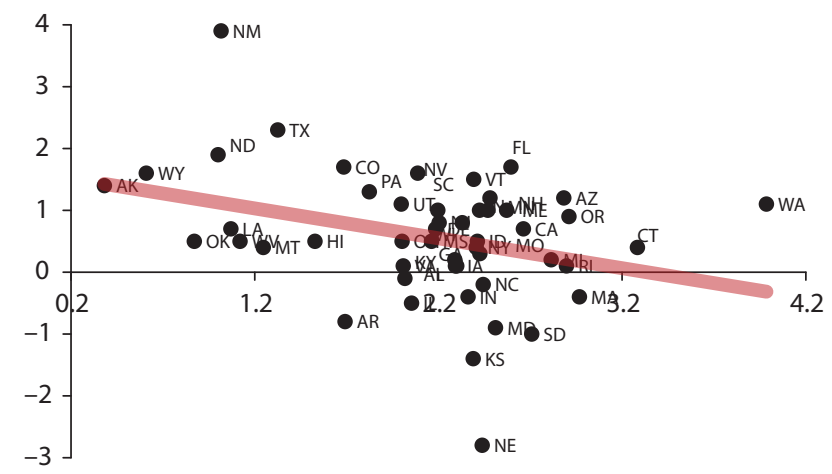

Total exposure to China
B. Employment growth

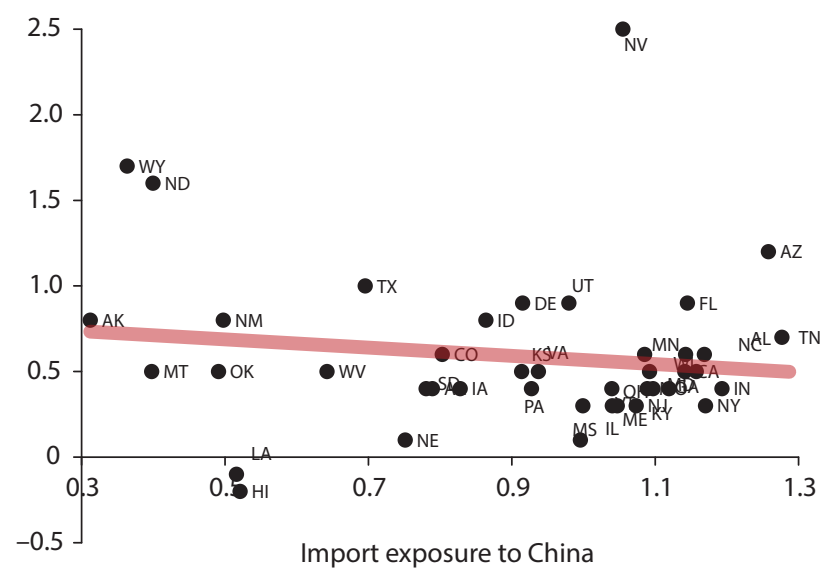

D. Employment growth

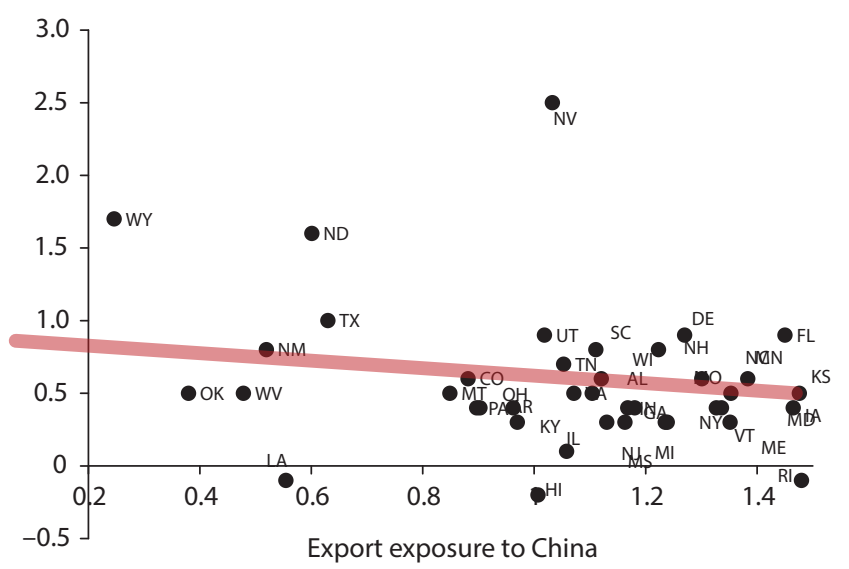

F. Employment growth

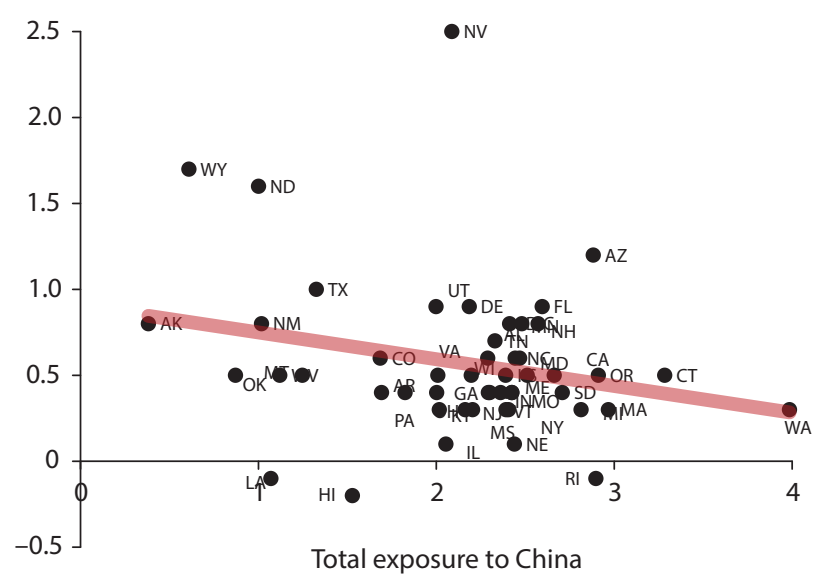

NOTE: This figure plots, in the $x$-axis, heterogeneity in import exposure (Panels $A$ and $B$ ), export exposure (Panels $C$ and $D$ ), and total exposure (Panels E and F), and relates them to GDP growth and employment growth for 2018:Q1-2019:Q1 (y-axis).

SOURCE: Authors' calculations. 
Overall, we find that heterogeneous trade exposure to China translated into variation in economic activity across U.S. states. The impact, however, was weaker than in the case of U.S. variation in trade exposure to the world. $\underline{18}$

\section{CONCLUSION}

We have exploited cross-state variation in trade exposure and related it to U.S. economic outcomes in terms of both employment and output growth during the past year. States that were more exposed to trade with the world have performed worse in terms of employment and output growth than have states that were less exposed. Although we cannot claim any causality effects in this analysis, our findings suggest that the trade war initiated by the United States may have had a stronger impact on the U.S. economy than what standard models of trade have found. Accounting for state heterogeneity is thus key in capturing the negative impacts of tariff increases.

We have abstracted from several interesting channels through which tariffs could impact economic activity. However, we have not taken into account spillovers across U.S. states. If we had observed inter-state trade flows, our measure of state exposure would also account for imports from other highly exposed states. Furthermore, increases in tariffs could reallocate imports away from foreign countries and toward other U.S. states, affecting state exposure to trade. We did not look at this channel because of data limitations on inter-state trade for the sectors in our analysis. This channel, however, has been recently explored, through the lens of a quantitative model of trade, by Santacreu, Sposi, and Zhang (2019). They infer missing trade flows between U.S. states using gravity methods and find that accounting for internal flows has significant effects on welfare. 


\section{Santacreu and Peake}

\section{APPENDIX}

\section{Data Sources}

\section{Table A1}

\section{Raw Data and Sources}

\begin{tabular}{lcc} 
Variable & Source & Period \\
\hline Intermediate, final goods (imports and exports, millions current USD) & WIOD & 2014 \\
\hline Output (value added) by state and sector (GDP, millions current USD) & BEA & 2014 \\
\hline GDP by state (GDP, real millions 2012 chained USD) & BEA & $2017-19$ \\
\hline Employment by state (Q1, goods, private industries) & BLS & $2017-19$ \\
\hline Goods, tariffs imposed by U.S. and China & PIIE & 2018-current \\
\hline NOTE: USD, U.S. dollars; WIOD, World Input-Output Database; BEA, Bureau of Economic Analysis; BLS, Bureau of Labor \\
Statistics; PIIE, Peterson Institute for International Economics.
\end{tabular}

\section{Table A2}

\section{Industry List}

Industry description and code

\begin{tabular}{ll}
\hline Agriculture & 1 \\
\hline Forestry, fishing, and logging & 2 \\
\hline Mining and quarrying & 3 \\
\hline Food, beverage, and tobacco & 4 \\
\hline Textiles and leather & 6 \\
\hline Wood and cork & 7 \\
\hline Paper, paper products, and printing & 8 \\
\hline Coke and petroleum & 9 \\
\hline Chemicals and pharmaceuticals & 10 \\
\hline Rubber and plastic products & 11 \\
\hline Other non-metallic mineral products & 12 \\
\hline Basic metals & 13 \\
\hline Fabricated metals, except machinery and equipment & 14 \\
\hline Computer, electronic, and optical & 15 \\
\hline Electrical equipment & 16 \\
\hline Machinery and equipment, n.e.c. & 17 \\
\hline Motor vehicles and trailers & 18 \\
\hline Other transport equipment & 19 \\
\hline Furniture and other manufacturing & \\
\hline
\end{tabular}


Figure A1

\section{Sectoral Import and Export Exposure to the World}

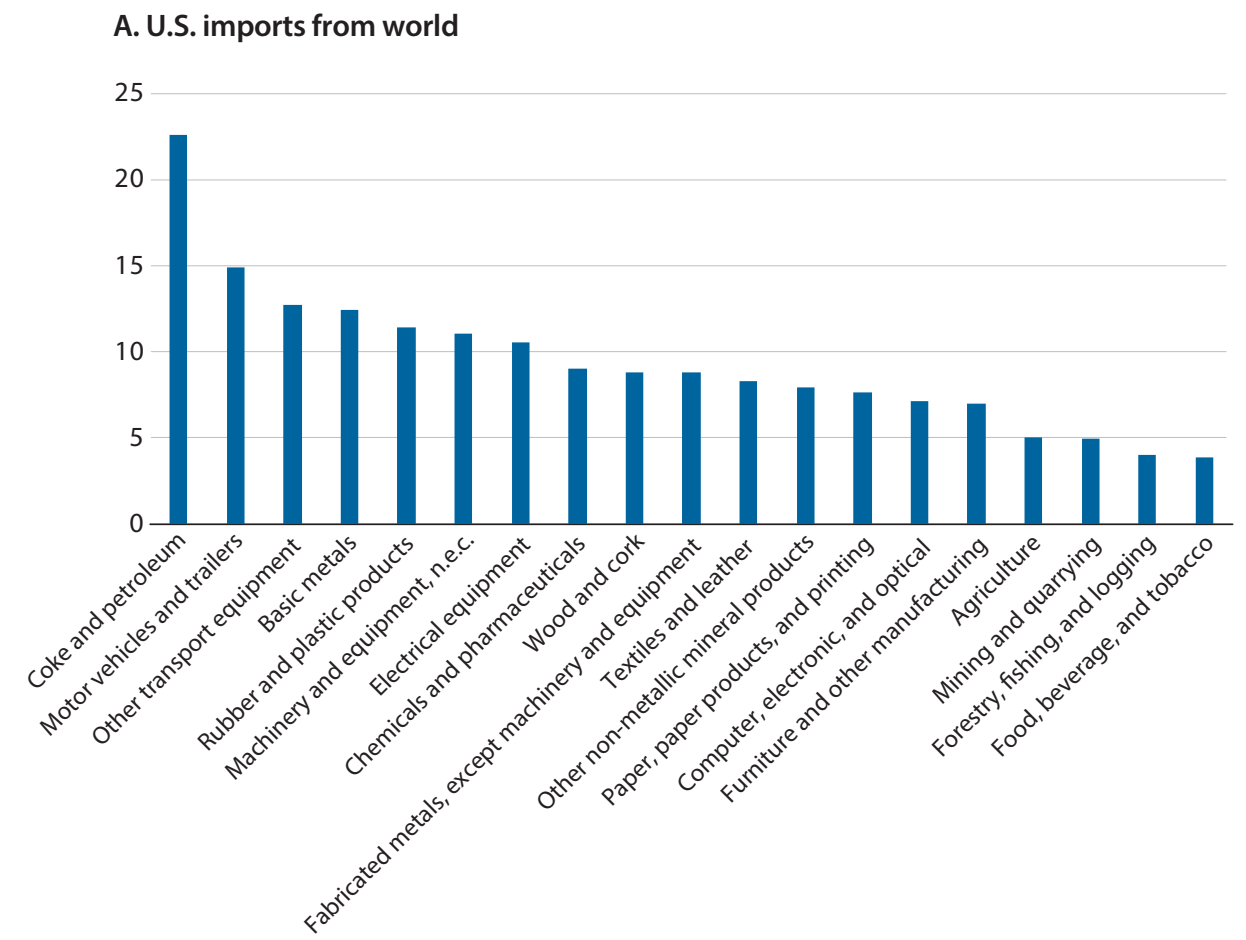

\section{B. U.S. exports to world}

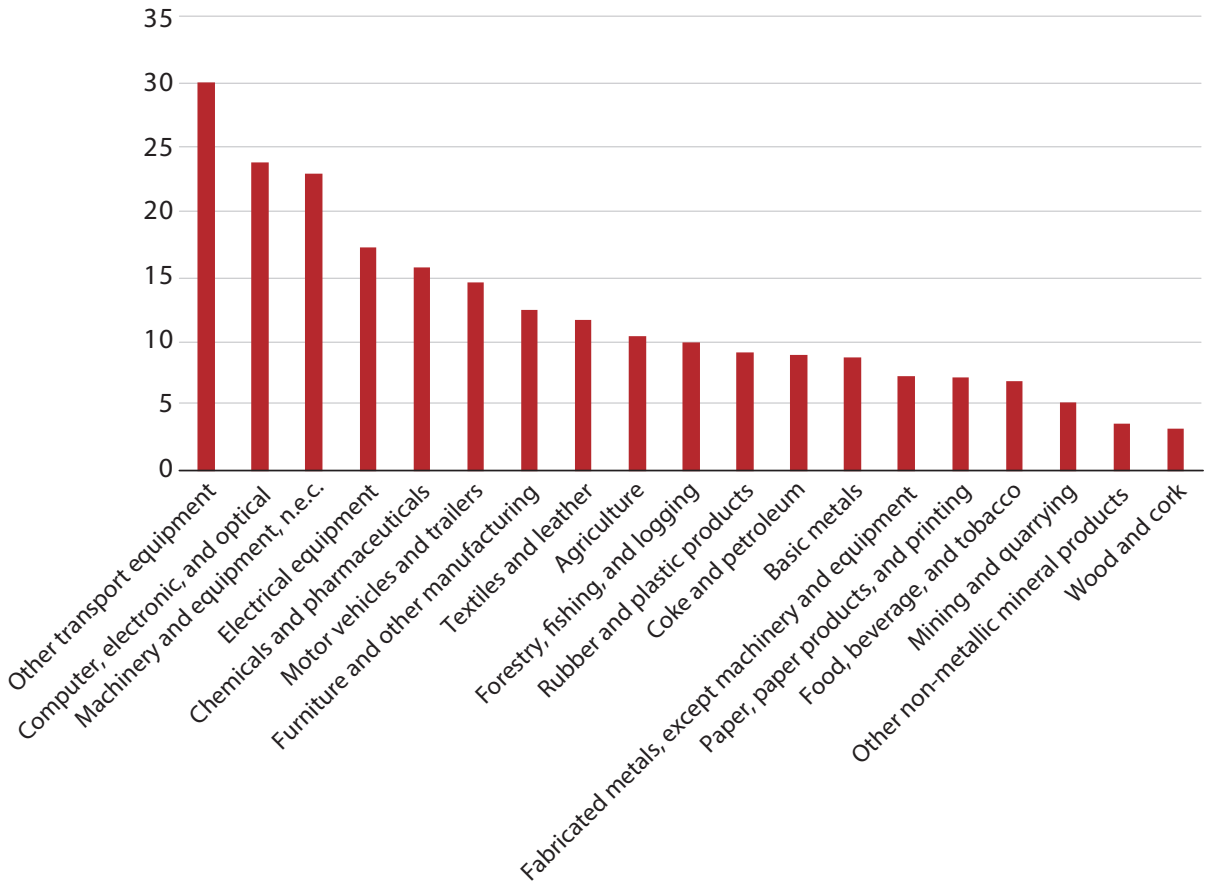

SOURCE: Authors' calculations. 


\section{Santacreu and Peake}

Figure A2

Sectoral Import and Export Exposure to China

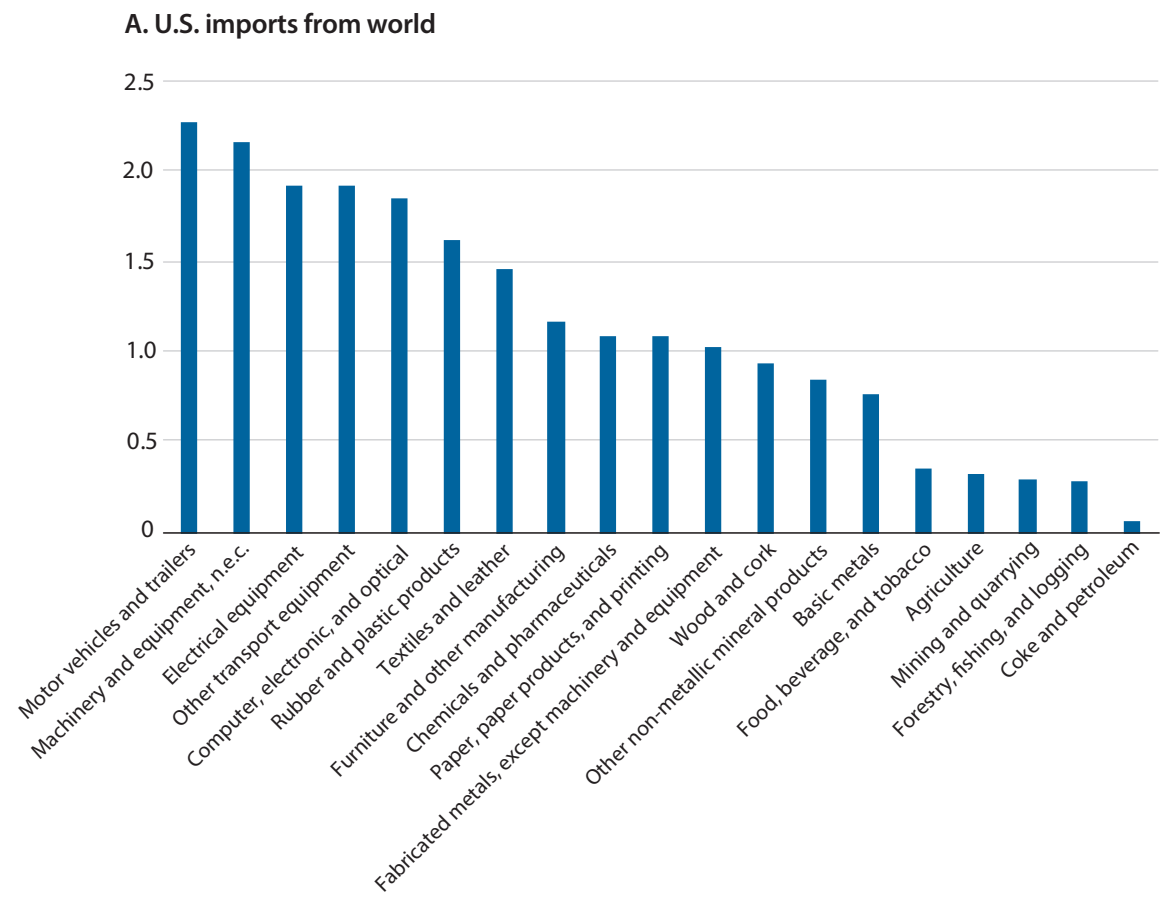

B. U.S. exports to world

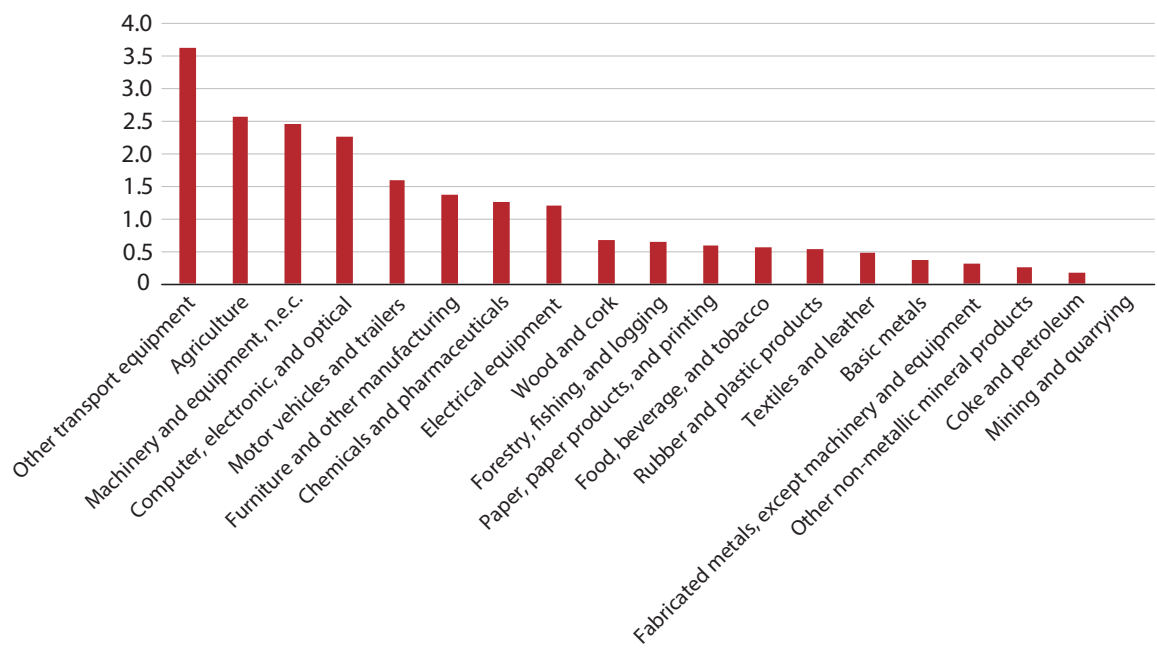




\section{Figure A3}

Trade Exposure to World and Economic Activity, 2018:Q1-2019:Q1, Weighted by State Population in 2019

\section{A. GDP growth}

4.0
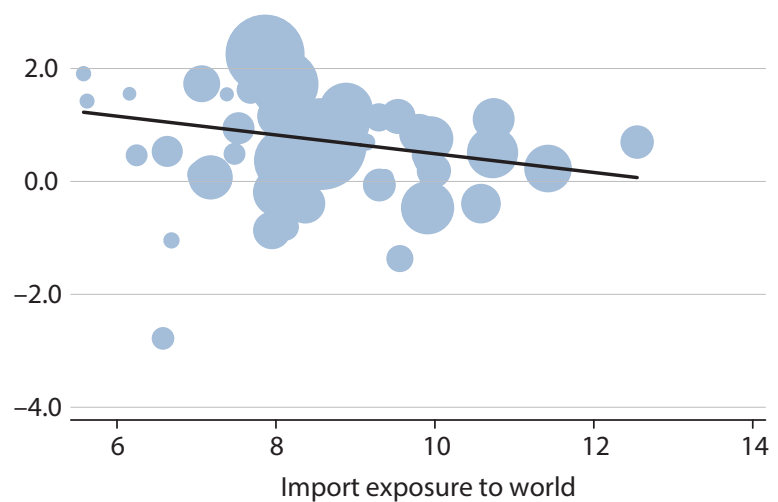

C. GDP growth

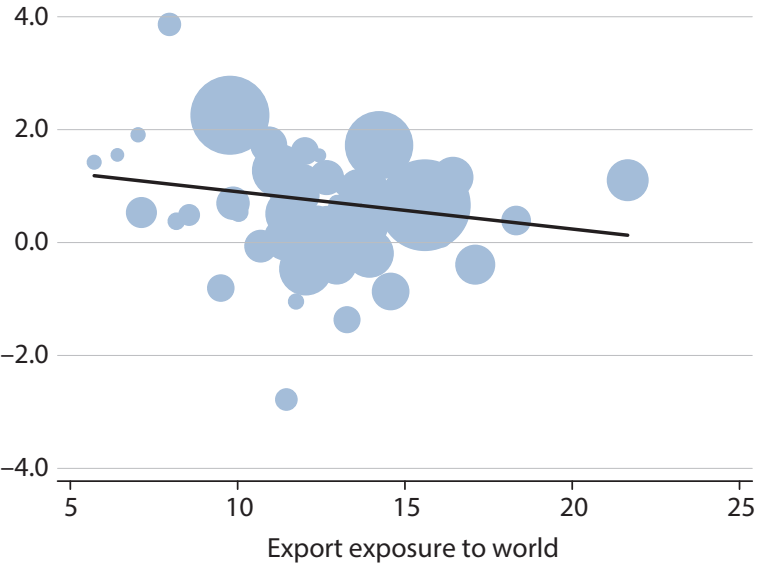

E. GDP growth

4.0

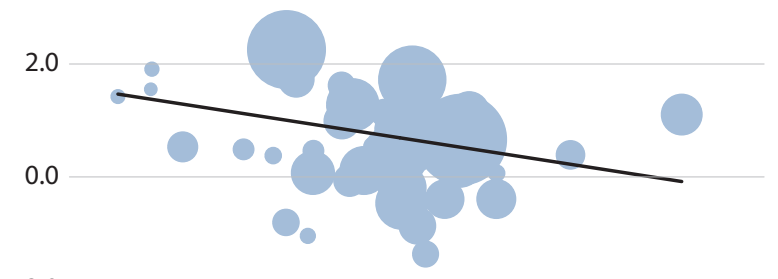

$-2.0$

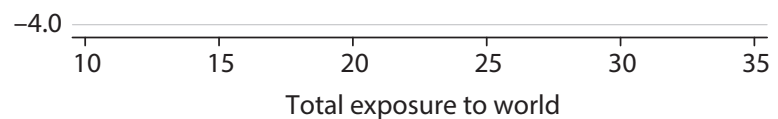

B. Employment growth

3.0

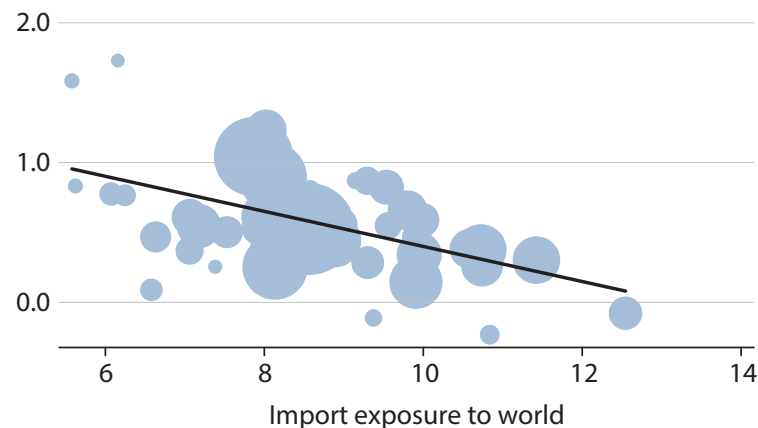

D. Employment growth

3.0

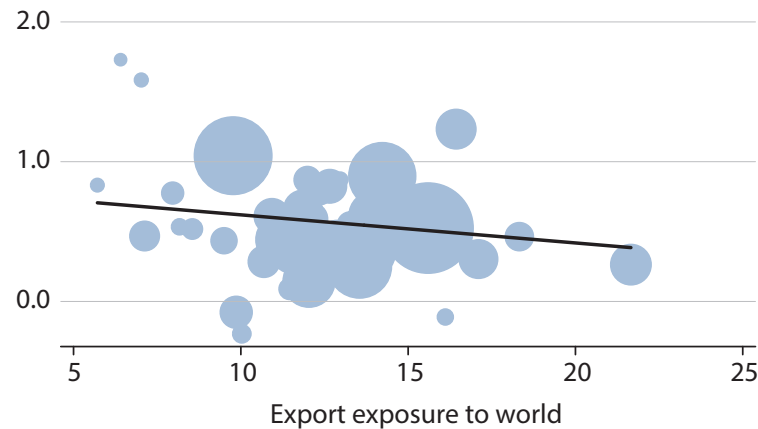

F. Employment growth

3.0

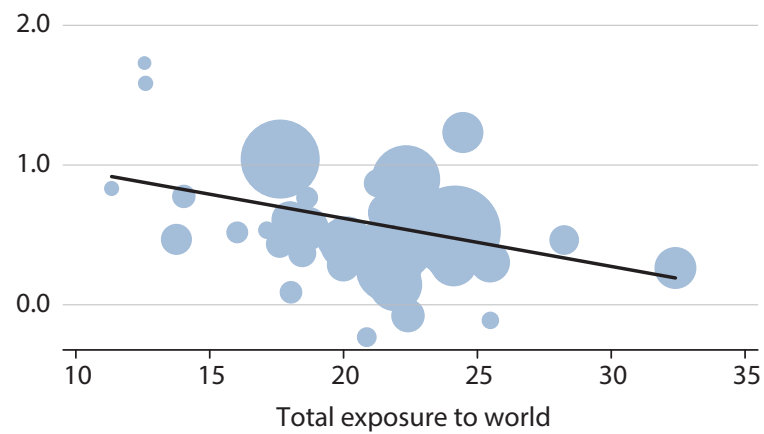

NOTE: This figure plots, in the $x$-axis, heterogeneity in import exposure (Panels $A$ and $B$ ), export exposure (Panels $C$ and D), and total exposure (Panels E and F), and relates them to GDP growth and employment growth for 2018:Q1-2019:Q1 (y-axis) while weighting by state population as of 2019.

SOURCE: Authors' calculations. 


\section{Figure A4}

Trade Exposure to China and Economic Activity, 2018:Q1-2019:Q1, Weighted by State Population in 2019

\section{A. GDP growth}

4.0

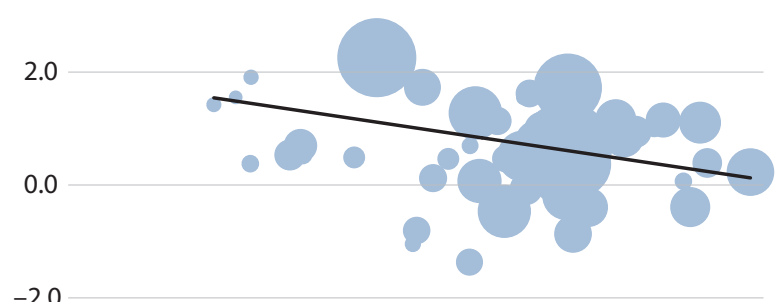

$-2.0$

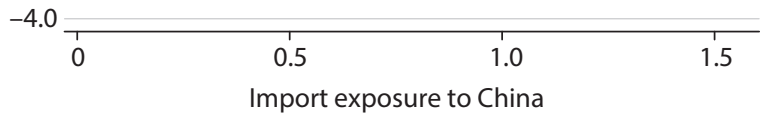

C. GDP growth

4.0
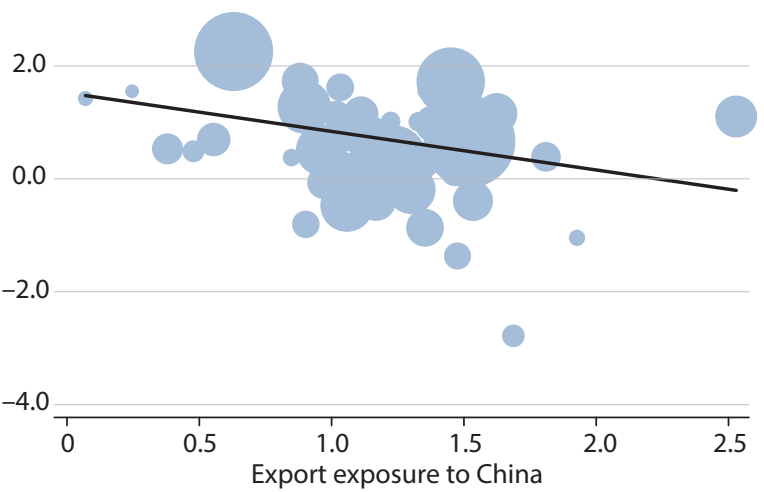

E. GDP growth

4.0

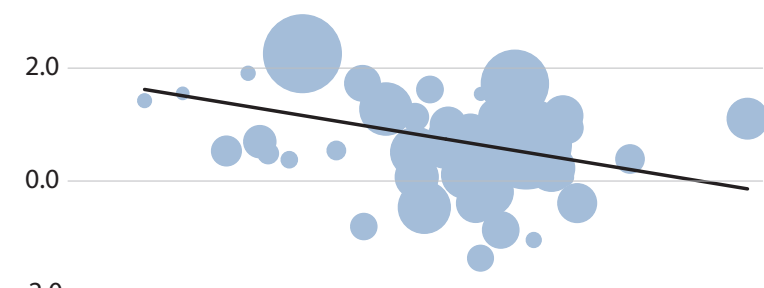

$-2.0$

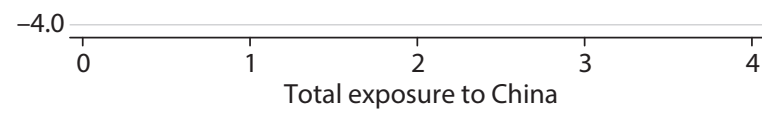

B. Employment growth

3.0

2.0

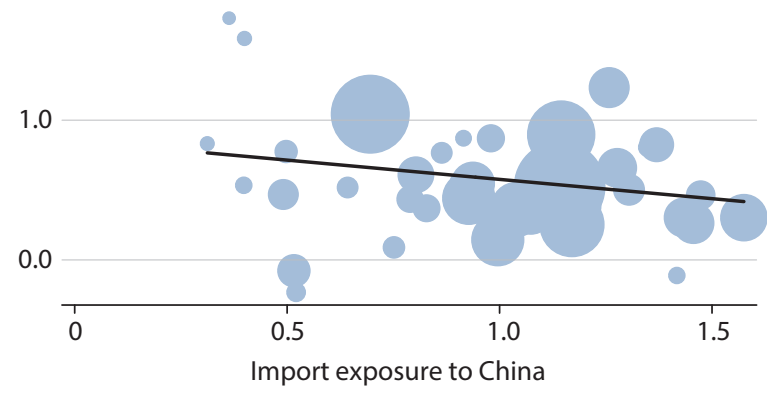

D. Employment growth

3.0

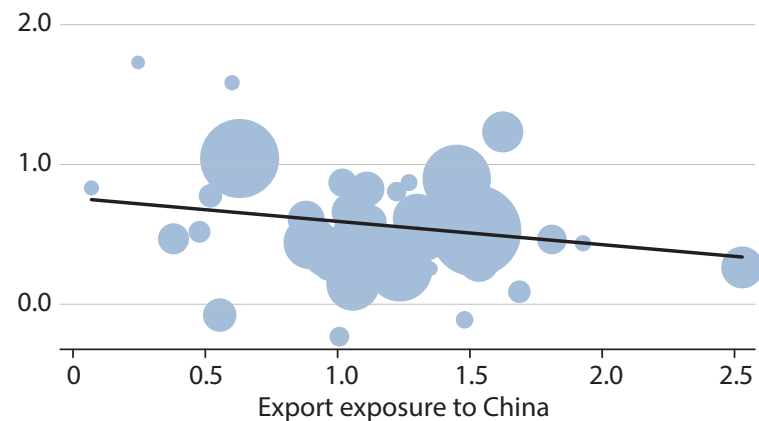

F. Employment growth

3.0

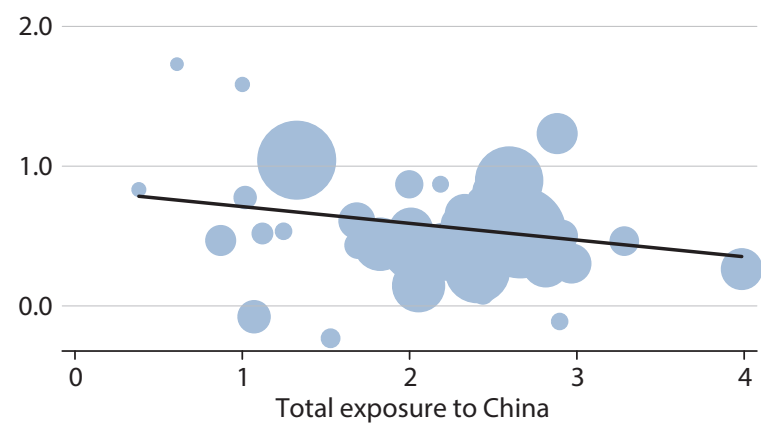

NOTE: This figure plots, in the $x$-axis, heterogeneity in import exposure (Panels $A$ and $B$ ), export exposure (Panels $C$ and $D$ ), and total exposure (Panels E and F), and relates them to GDP growth and employment growth for 2018:Q1-2019:Q1 ( $y$-axis) while weighting by state population as of 2019.

SOURCE: Authors' calculations. 


\section{NOTES}

1 Bown and Kolb (2020).

$\underline{2}$ In 2019, they accounted for over 60 percent of total trade with the United States.

3 As noted in Santacreu, Sposi, and Zhang (2019), U.S. states are also exposed differently to trade based on characteristics other than their comparative advantage, such as their geography.

4 This measure of trade exposure captures direct effects of international trade policy on each sector. However, we are not taking into account the complete input-output structure, as we do not look at whether the sector is using intermediate inputs from other U.S. sectors that are heavily exposed to imports or exports.

$\underline{5}$ In Figure A1 in the appendix, we plot our measure of sectoral trade exposure for all 19 industries in our sample.

6 A better measure of exposure would rely on trade data at the state and sector level. That is, $E_{\mathrm{Us,W}}^{j, s}=\frac{X_{\mathrm{W}}^{j, s}}{G O_{s}^{j,}}$, where $X_{\mathrm{W}}^{j, s}$ represents trade flows of each state $s$ in sector $j$ with the world, and $G O_{s}^{j}$ is gross output of state $s$ in sector $j$. However, because of data limitations, we use equation (2).

$\underline{7} \operatorname{Kolmar}(2020)$.

$\underline{8}$ Data sources: https://beta.bls.gov/maps/cew/us and https://apps.bea.gov.

9 Figure $\mathrm{A} 3$ in the appendix shows the results taking into account each state's population in 2019. Our findings are robust to using weighted regression with state population as the weight.

10 Parilla and Bouchet (2018)

11 China's implementation of tariffs on the U.S. Agriculture sector follows a recent report from the Congressional Research Service (Regmi, 2019) claiming that China has retaliated in response to U.S. tariffs by adding tariffs to 94 different U.S. food and agricultural products as of April 2018.

$\underline{12}$ In Figure A2 in the appendix, we plot sectoral trade exposure to China for all 19 industries in our sample.

13 A recent article on the industries most impacted by the U.S.-China trade war (Reiff, 2019) lists the U.S. automobile industry as the most impacted by tariffs.

14 Tonneson (2017).

15 These states had among the lowest imports from China in 2018. See Kiersz and Heeb (2019).

16 Further evidence from an article on the trade war (Soergel, 2019) lists Washington as one of the top states exporting to China.

17 A recent article published by Bloomberg (Gongloff, 2019) highlights the dangers ahead for Michigan, as the state's annual growth rate in manufacturing employment has slowed down significantly.

18 Figure A4 in the appendix shows the results taking into account each state's population in 2019. Our findings are robust to using weighted regression with state population as the weight.

\section{REFERENCES}

Amiti, Mary; Redding, Stephen J. and Weinstein, David E. "The Impact of the 2018 Tariffs on Prices and Welfare." Journal of Economic Perspectives, 2019, 33(4), pp. 187-210; https://doi.org/10.1257/jep.33.4.187.

Auer, Raphael; Bonadio, Barthélémy and Levchenko, Andrei A. "The Economics and Politics of Revoking NAFTA." NBER Working Paper No. w25379, 2018; https://doi.org/10.3386/w25379.

Bloom, Nick; Bond, Stephen and Van Reenen, John. "Uncertainty and Investment Dynamics." Review of Economic Studies, 2007, 74(2), pp. 391-415; https://doi.org/10.1111/j.1467-937X.2007.00426.X.

Bown, Chad and Kolb, Melina. "Trump's Trade War Timeline: An Up-to-Date Guide." Peterson Institute for International Economics, March 13, 2020, update;

https://www.piie.com/sites/default/files/documents/trump-trade-war-timeline.pdf. 


\section{Santacreu and Peake}

Caldara, Dario; lacoviello, Matteo; Molligo, Patrick; Prestipino, Andrea and Raffo, Andrea. "The Economic Effects of Trade Policy Uncertainty." Journal of Monetary Economics, 2019; https://doi.org/10.1016/j.jmoneco.2019.11.002.

Fajgelbaum, Pablo D.; Goldberg, Pinelopi K.; Kennedy, Patrick J. and Khandelwal, Amit K. "The Return to Protectionism." NBER Working Paper No. 25638, 2019; https://doi.org/10.3386/w25638.

Gongloff, Mark. "Trump's Trade War Is Hurting His 2018 Swing States." Bloomberg, 2019; https://www.bloomberg.com/opinion/articles/2019-10-02/trump-s-trade-war-hurts-his-2016-swing-states.

Handley, Kyle and Limão, Nuno. "Trade and Investment Under Policy Uncertainty: Theory and Firm Evidence." American Economic Journal: Economic Policy, 2015, 7(4), pp. 189-222; https://doi.org/10.1257/pol.20140068.

Handley, Kyle and Limão, Nuno. "Policy Uncertainty, Trade, and Welfare: Theory and Evidence for China and the United States." American Economic Review, 2017, 107(9), pp. 2731-83; https://doi.org/10.1257/aer.20141419.

Kiersz, Andy and Heeb, Gina. "Trump's Trade War with China Is About to Get Worse: These Maps Show Which States Could Be Most Affected." Markets Insider, 2019; https://markets.businessinsider.com/news/stocks/mapsbiggest-trading-partners-trade-with-china-by-state-2019-8-1028488609.

Kolmar, Chris. "The 100 Largest Companies in Louisiana for 2020." Zippia, 2020. https://www.zippia.com/advice/largest-companies-in-louisiana/.

Mian, Atif and Sufi, Amir. "The Consequences of Mortgage Credit Expansion: Evidence from the U.S. Mortgage Default Crisis." Quarterly Journal of Economics, 2009, 124(4), pp. 1449-96; https://doi.org/10.1162/ajec.2009.124.4.1449.

Parilla, Joseph and Bouchet, Max. "Which US Communities Are Most Affected by Chinese, EU and NAFTA Retaliatory Tariffs?" Brookings, 2018; https://www.brookings.edu/research/which-us-communities-are-most-affected-by-chinese-eu-and-nafta-retaliatory-tariffs/.

Regmi, Anita. “China's Retaliatory Tariffs on U.S. Agriculture: In Brief." Congressional Research Service, 2019; https://fas.org/sgp/crs/row/R45929.pdf.

Reiff, Nathan. "The Top 3 Industries Affected by the Trade War with China." Investopedia, 2019; https://www.investopedia.com/industries-most-likely-to-be-impacted-by-trade-disputes-with-china-in-2019-4580508.

Santacreu, Ana Maria; Sposi, Michael and Zhang, Jing. "A Quantitative Analysis of Tariffs across U.S. States." Unpublished manuscript, 2019.

Soergel, Andrew. "These 5 States Trade the Most with China." US News, 2019; https://www.usnews.com/news/best-states/slideshows/these-states-trade-the-most-with-china?onepage.

Tonneson, Lon. "South Dakota's Top Crops." Farm Progress, 2017; https://www.farmprogress.com/corn/south-dakota-s-top-crops. 